\title{
LA MiNO DEL DHO
}

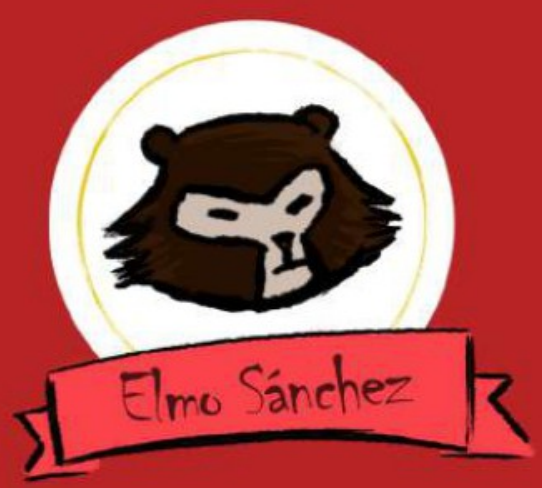




\section{La mano del oso:}

detalles del desarrollo de la novela gráfica

Trabajo de grado elaborado por:

Diana Lucía Caicedo Suárez

Directora trabajo de grado:

María Claudia Parias Durán

Maestría en Gestión y Producción Cultural y Audiovisual

Facultad de Ciencias Sociales

Universidad Jorge Tadeo Lozano

Derechos Reservados

2020 
El cómic es un fenómeno universal que se asocia con la adolescencia. Por lo que parece, existe en todos los idiomas y culturas, de Oriente a Occidente. Abarca toda clase de temáticas, desde las más inspiradas y fantásticas hasta las más sentimentales y bobas...

Cualquier cómic resulta, sin embargo, fácil de leer, prestar, guardar y tirar. Muchos constituyen, como Asterix o Tintín, aventuras seriadas pensadas para unos jóvenes que las leen fielmente mes tras mes; con el tiempo, al igual que ha pasado con los dos que acabo de mencionar, parecen adquirir vida propia, con personajes recurrentes, tramas o frases que convierte a sus lectores, ya sea en Egipto, Ia India o Canadá, en una especie de club cuyos miembros se saben de memoria y son capaces de referir todo un conjunto de nombres y situaciones. La mayoría de los adultos, según creo, tiende a relacionar los cómics con lo frívolo o efímero, y ha interiorizado la noción de que, a medida que uno se hace mayor, los va dejando de lado para dedicarse a asuntos más serios, excepto cuando se da la remota circunstancia (como sucede con el Maus de Art Spiegelman) en la que una materia ominosamente sombría es tratada por un autor de cómics serio. En todo caso, y como ya veremos ahora mismo, tales eventualidades son realmente raras, en tanto en cuanto lo primero se requiere un talento excepcional.

Soy incapaz de recordar exactamente cuándo leí mi primer cómic, pero lo que sí recuerdo con absoluta precisión es lo liberado y subversivo que me sentí al hacerlo. Todo lo que rodeaba a aquel apasionante libro de dibujos coloreados, en especial la extensión y desorden en cuanto formato, la extravagancia desenfrenada de sus imágenes, los saltos sin solución de continuidad entre los pensamientos y diálogos de los personajes, las criaturas exóticas, o las aventuras narradas y representadas... Todo esto, decía, me suscitó una emoción inmensa, sensacional y de un carácter totalmente distinto a cualquier cosa que hubiera conocido o experimentado hasta el momento.

(Edward Said. Homenaje a Joe Sacco. Palestina. 2015, P. 5) 


\title{
Resumen
}

El presente documento recoge los pasos que se han seguido para la creación de la novela gráfica La mano del oso, texto e ilustración, que ordenado por medio de viñetas cuenta con una secuencialidad narrativa, que desde la ficción habla sobre la situación de vulnerabilidad del oso de anteojos (Tremarctos ornatus) en Colombia. Puesto que el proyecto aborda desde la creación hasta la comercialización del libro, el presente texto se ocupa -de acuerdo a sus capítulos- en dar un vistazo por el cómic como herramienta pedagógica y narrativa (tanto para la ficción como para la no ficción), aborda un poco los procesos de creación, comenta acerca del mercado editorial en Colombia, y por supuesto da una mirada a la empresa, que resulta ser la plataforma que permite la creación de la novela gráfica y otros proyectos artísticos de los que se comentará brevemente. Es importante mencionar que a la fecha el proyecto aún está en desarrollo.

Palabras clave: Novela gráfica, cómic, editorial, oso de anteojos, oso andino, gestión cultural, empresa creativa y cultural, proyectos artísticos.

\begin{abstract}
The following document collects the steps that have been followed for the creation of the graphic novel: La Mano del Oso. The text and illustration have been sequenced in comic strips, which addresses from a fiction point of view, the spectacled bear's (Tremarctos ornatus) situation of vulnerability in Colombia. The project addresses the entire process, from the creation to the commercialization of the book. The following text takes care of - according to its chapters- giving an insight of the comic as an educational and narrative tool (both in fiction and nonfiction), tackles a little the process of the creation, comments about the editorial market in Colombia, and of course gives an insight to the company. This company ends up being the platform that allows the creation of the graphic novel and other artisticals projects that will be mentioned briefly. It is important to mention that the date of the project is still in development.
\end{abstract}

Keywords: Graphic novel, comic, editorial, spectacled bear, andinan bear, cultural management, creative and cultural company, artistic projects. 


\section{TABLA DE contenido}

INTRODUCCIÓN CAPÍTULO 2: MODELO DE

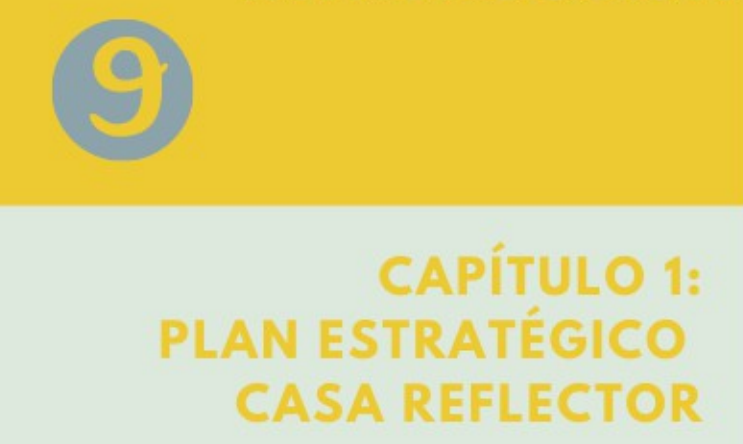

1.1. Descripción de la entidad 1.2 Misión 1.3 Visión

1.4 Filosofía corporativa 1.4.1 Principio 1.4.2 Marco Ético 1.4.3 Campo de acción 1.4.4 Grupos de interés 1.4.5 Objetivos organizacionales 1.5 Operacionalización 1.5.1 Alcance de la acción 1.5.2 Modelo de intervención 1.5.3 Presencia territorial

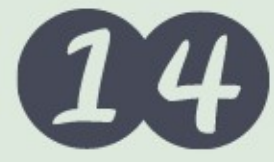

1.5.4 Medición 1.6 Dofa 1.7 Organigrama
NEGOCIO PARA LA MANO DEL OSO

2.1 Segmentos del mercado

2.2 Propuesta de valor

2.3 Canales

2.4 Relaciones con clientes

2.5 Fuentes de ingresos

2.6 Recursos clave

2.7 Actividades clave

2.8 Asociaciones clave

2.9 Estructura de costos

2.10 Análisis del entorno

editorial en Colombia

2.11 Aspectos jurídicos

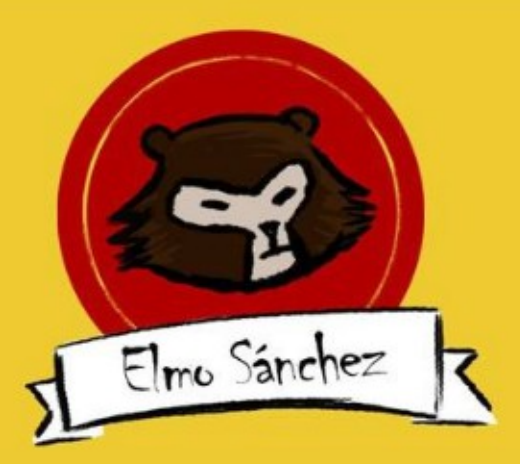




\section{CAPÍTULO 3: PROYECTO LA MANO DEL OSO}

\section{CONCLUSIONES}

3.1 Resumen ejecutivo

3.2 Diagnóstico y problemática

3.3 Profundización temática

$y$ referentes

3.4 Justificación

3.5 Objetivo general

3.6 Objetivo específicos

3.7 Metas

60

3.8 Presupuesto

3.9 Cronograma

5. BIBLIOGRAFIA

O LISTADO DE

REFERENCIAS

CONSULTADAS

\section{LISTA DE anexos}

1.Resultados recorrido

Directo Memoria

2. Resultados Convocatoria FLIP

La mano del oso

3. Soporte teórico

La mano del oso

4. Convenio Fundación Uraku

5. Evidencias gestión

La mano del oso

6. Historia y fotografías

Casa Reflector
7. Manual de experiencias

Casa Reflector

8. Tabla convocatorias novela gráfica

9. Bases de datos aliados y proveedores

10. Canvas La mano del oso

11. Presupuesto y cronograma

La mano del oso

12. Guion La mano del oso

13. Avance machote

La mano del oso 


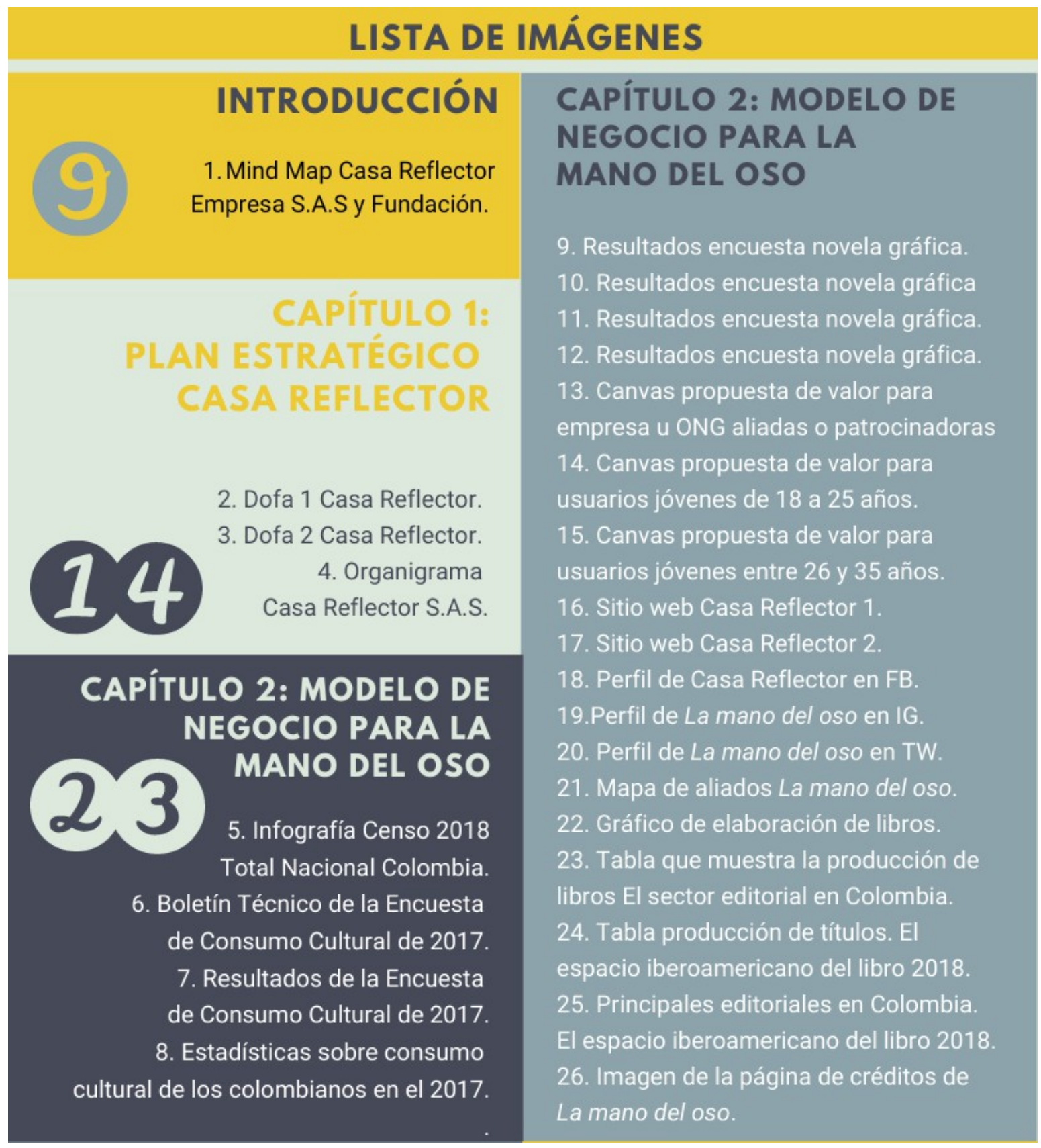




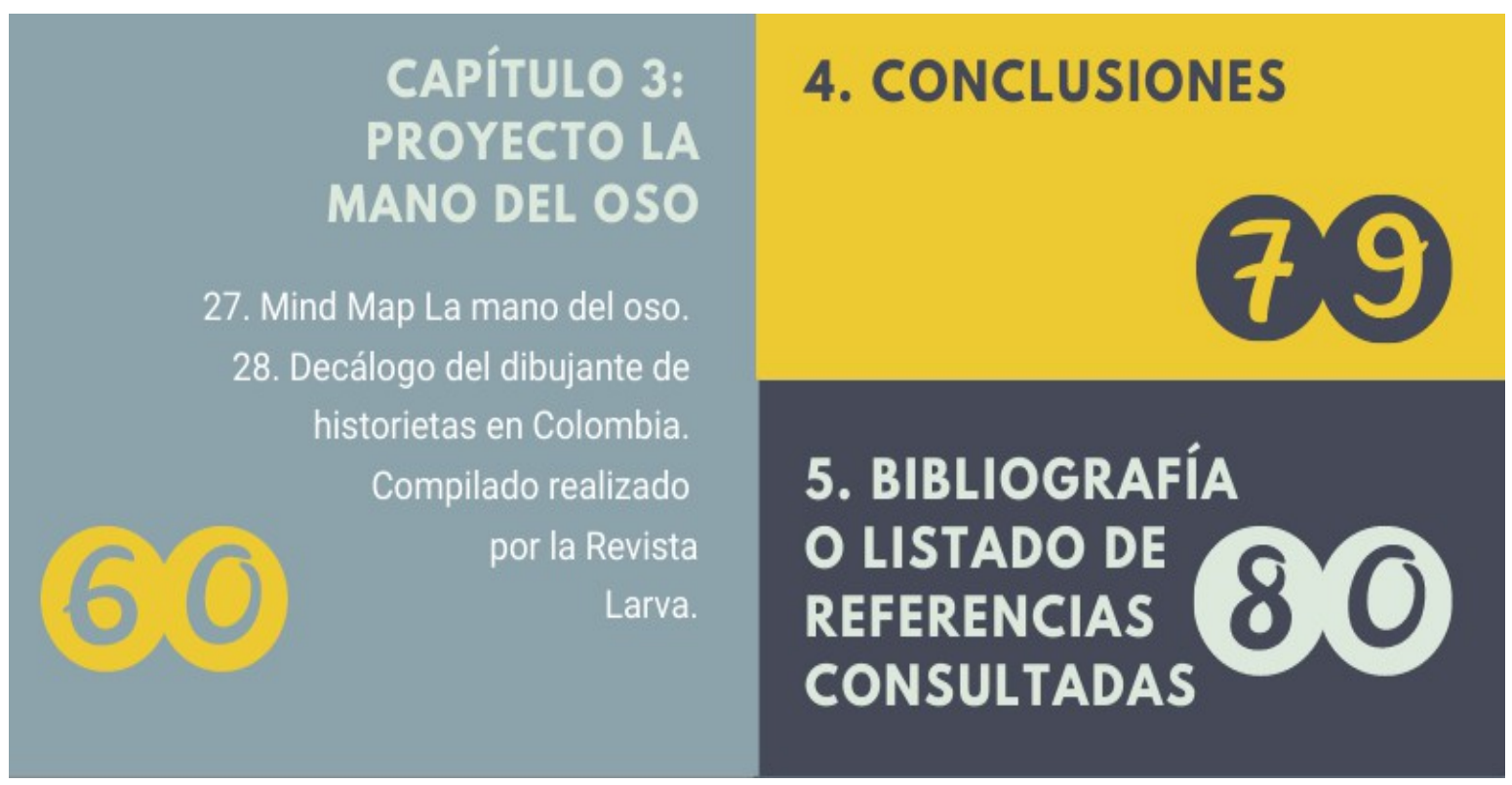




\section{Introducción}

Tal vez en otros oficios la realización de un trabajo de grado, se pueda escribir en tercera persona, pero en el caso de una maestría en gestión cultural y particularmente en esta ocasión, resulta difícil asumir una posición distante, puesto que el desarrollo de este trabajo está totalmente relacionado con opciones de vida, por tanto, esta introducción además de ser escueta, será escrita desde la libertad de la primera persona.

Casa Reflector, la empresa S.A.S y la Fundación son una apuesta que llevo adelantando hace más de cinco años. A lo largo de este tiempo, además de trabajar de manera paralela en diferentes instituciones y/o empresas, he participado y ganado varias convocatorias que me han permitido llevar a cabo los proyectos que he planeado con mis dos socios.

Sin embargo, aquí surge la duda que motiva este trabajo de grado: ¿Cómo hacer sostenible la empresa?

Casa Reflector no se plantea como una empresa común, no nos hemos perfilado como una productora de audiovisuales, no vendemos servicios, no desarrollamos publicidad o proyectos institucionales. Somos una empresa que quiere crear propuestas o proyectos artísticos -ojalá- híbridos, que aborden temas especializados en diversas áreas del conocimiento como historia, medioambiente, libertad de género y/o sexual, entre otros.

Generalmente nuestros proyectos cuentan con la asesoría de expertos o con la participación de personas vinculadas a estos temas o situaciones. Buscamos generar o apoyar estrategias educativas desde la generación de contenidos, así, uno de nuestros objetivos es despertar reconsideraciones, llevar la mirada del público hacia esos temas que habitualmente han sido señalados como aburridos para cambiar la percepción de los mismos y lograr profundizar un poco en ellos. 


\section{盲 REAAECTOR}

\section{MIND MAP}

EMPRESA S.A.S. Y FUNDACIÓN

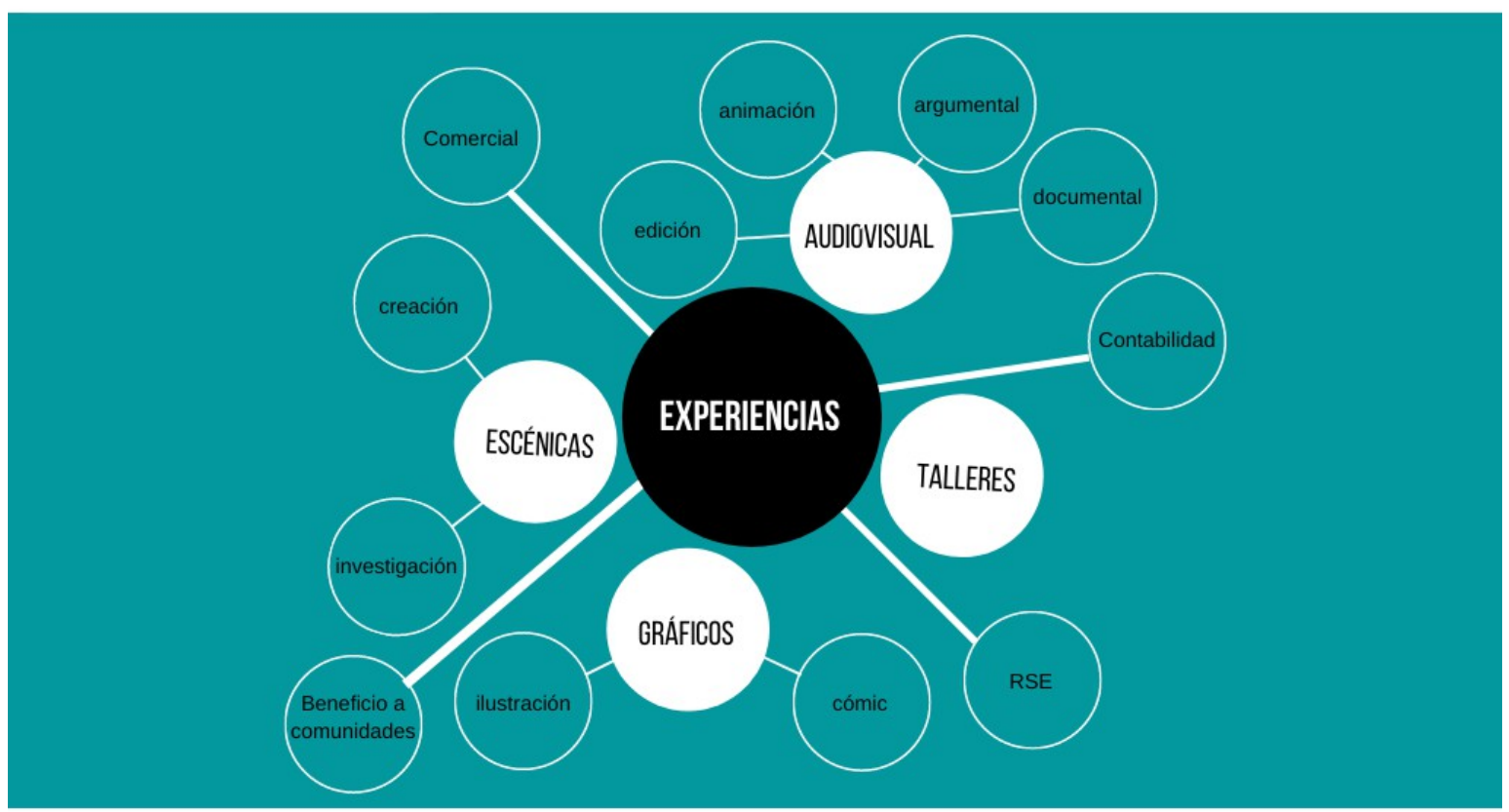

WWW.CASAREFLECTOR.COM

1. Mind Map Casa Reflector Fuente: Elaboración propia.

A partir de esa pregunta, mi primer objetivo para este trabajo de grado fue desarrollar proyectos que sirvieran para evaluar dos posibles líneas de negocios, así nacieron el recorrido turístico teatralizado Directo memoria y la novela gráfica La mano del oso.

Durante 2019 se conceptualizó alrededor de los dos proyectos, se generaron propuestas y ganamos dos convocatorias que permitieron el desarrollo de la prueba piloto del recorrido y la creación de la primera parte de la novela gráfica. Esos adelantos permitieron realizar de una evaluación desde la viabilidad económica, revisando los recursos humanos y técnicos invertidos, frente a los resultados obtenidos, así como el impacto esperado en el público. Viendo que el proceso de la novela gráfica se encontraba más adelantado, y podía llegar a mejores resultados, en un lapso de tiempo más breve, se optó por continuar el presente trabajo de grado con el desarrollo exclusivo de este proyecto. 
Si bien los resultados obtenidos en la prueba piloto del recorrido teatralizado los encontrarán entre los anexos, el propósito de este proyecto es abarcar el desarrollo de la novela gráfica.

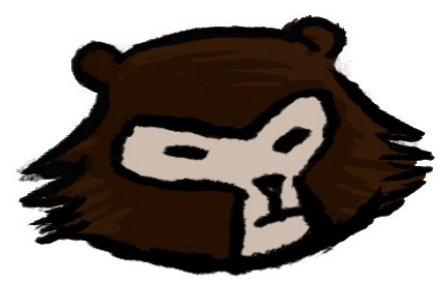

Gracias a la beca que recibimos de la Fundación para la Libertad de Prensa -FLIP- en 2019, se desarrolló la primera parte de la novela gráfica La mano del oso e iniciamos el trabajo en redes sociales con el personaje.

Para la escritura de la sinopsis y el guion tomamos como punto de partida el estudio de material de prensa y la consulta de varias cartillas que nos permitieron crear un texto de soporte teórico (adjunto en los anexos), el cual consultamos para descartar dudas al momento de escribir. Así mismo, contamos con la asesoría científica de WCS, entidad no gubernamental que opera a nivel mundial buscando la conservación de especies y hábitats. También contamos con el apoyo y asesoría de Fondo Acción, entidad no gubernamental que opera en Colombia gracias a fondos extranjeros y que trabajan junto con las comunidades en la conservación del medioambiente desarrollando, en muchos casos, la idea de paz ambiental.

Ya en 2020, llevamos a cabo gestiones para proponer al diario El Espectador un espacio paralelo al libro donde desde el personaje de Elmo Sánchez se aborden otros temas o problemas del medioambiente, en este momento estamos aguardando su respuesta.

De igual forma, hemos presentado el proyecto a editoriales, como Cohete Cómics quienes están abiertos al estudio de la propuesta una vez esté finalizada su creación y al Grupo Planeta, que aún estudia la propuesta, ésta en caso de ser positiva se concretaría hasta el 2021.

También en la búsqueda de alianzas que permitan llevar a buen término el proyecto ya se concretó un convenio de cooperación con la Fundación Uraku (incluido en los anexos), se 
conversó con el Santuario del Oso de Anteojos que se mostró interesado en el proyecto y se está presentando la iniciativa a entidades como ProCat, Fundación Wii, Parque Jaime Duque, Fundación Natura, la propuesta es invitarlos a hacer parte de la red de amigos de Elmo (entre los anexos se incluyen presentaciones y correos que muestran la gestión adelantada) y a que una vez esté finalizado el machote digital, estudien la posibilidad de compra de ejemplares del libro.

La situación generada por el COVID-19 ha exigido realizar ajustes al plan inicial, algunas ofertas de financiación no se concretaron, sin embargo, considero que el proyecto va por buen camino y que a la evaluación de este texto estaremos avanzando con la ilustración, lo que hace que el mayor de los objetivos propuestos este cerca de su finalización.

Teniendo en consideración lo comentado, a continuación, encontrarán el plan estratégico de la empresa, el proyecto de La mano del oso en su más reciente versión y el plan de negocios que es el proceso que estoy adelantando para hacerlo realidad.

Si bien al momento de escribir estas líneas, no he resuelto totalmente mi pregunta sobre la sostenibilidad de la empresa, (la novela gráfica está en desarrollo, el recorrido detenido por el COVID-19 y hay nuevos proyectos sobre la mesa) pienso que tal vez lo importante no sea la respuesta, sino la pregunta en sí misma, porque ésta fue la que me llevó a la acción, una que esperamos concluya no solo con la novela gráfica lista, sino con la posibilidad de llevar a cabo más proyectos que generen el movimiento de dinero que necesitamos para asegurar la tan anhelada sostenibilidad.

\section{Sobre los términos}

Durante el desarrollo del texto y teniendo como punto de partida las definiciones del Diccionario Panhispánico de dudas de la RAE, se usará la palabra cómic refiriéndose a la secuencia de viñetas con desarrollo narrativo, al libro o revista que tiene narración mediante viñetas, y se emplearán como sinónimos las palabras historieta(s), muñequito(s), monos o monitos (usados en Cuba y México), comiquitas (de uso frecuente en Venezuela) o el término tebeo (popular en España).

En cuanto a la expresión novela gráfica para definirla, se parte de la reflexión de autores como el español Santiago García y el colombiano Daniel Jiménez, director de la revista Larva dedicada al estudio y difusión del cómic, el fanzine y la novela gráfica creados en Colombia. 
Jiménez en un artículo para el Banco de la República, recoge su opinión y la de García de la siguiente manera:

"La novela gráfica contemporánea representa, pues, y más que nada, esa consciencia de libertad del autor, un movimiento que funda una tradición hermana de las demás, pero distinta". Así pues, comprendemos que la novela gráfica es un eje de creación, un inmenso territorio artístico, en el cual el cómic también habita desde su supuesta madurez, y un escenario que hoy en día representa uno de los mayores y más vibrantes compromisos que puede asumir un narrador y dibujante. (Jiménez, 2014, p.48)

Y más adelante en el mismo artículo amplía:

Al acercarse al acervo bibliográfico de la novela gráfica se podrá distinguir que hay títulos de treinta, sesenta, ochenta, cien, doscientas, quinientas o mil páginas que en forma indistinta reciben la etiqueta. Lo anterior se debe a que la novela gráfica, como he sostenido antes, es relativa más a una ambición creativa, a una forma de asumir el alcance y la versatilidad narrativa del cómic, que a un mero asunto de extensión. En este sentido, hay que diferenciar el uso de la palabra novela en su nombre, más allá de las relaciones que guarde con la novela literaria. Simplemente, fuera de la extensión, que es uno de los factores diferenciales en la etiqueta literaria, la novela gráfica es novela por su vicioso interés en el desarrollo elaborado de personajes y los rasgos de agudeza a la hora de proponer una estructura narrativa. (Jiménez, 2014, p.54)

Para completar y cerrar esta definición tomamos las palabras de Juan Conde en su artículo Del Cómic a la novela gráfica: mutaciones editoriales de la historieta colombiana en el siglo XXI:

Más allá de los modelos que puedan explicarla, o de las críticas y reticencias de algunos creadores de cómics frente a ella, la novela gráfica se ha convertido en una etiqueta frecuente en el sector editorial que no duda en denominar así a las narraciones gráficas, independientemente de su extensión, temática, enfoque o género. (Conde, 2019, p.63) 


\section{Capítulo 1: Plan estratégico Casa Reflector}

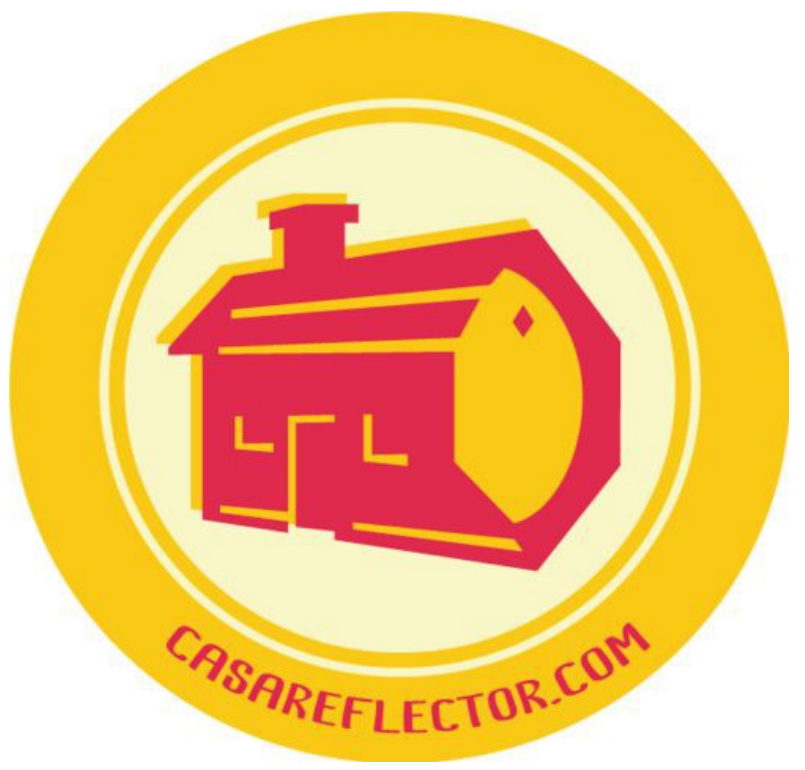

Desde Casa Reflector buscamos desarrollar un trabajo artístico que apoye y facilite procesos educativos estimulando entre los participantes de las experiencias, el amor por el conocimiento y el aprendizaje. Nuestra organización apuesta por la innovación mediante la combinación de lenguajes de las artes gráficas, audiovisuales y vivas para la creación de nuevas experiencias didácticas en temas que comprenden la historia, el patrimonio, el medioambiente, entre otros.

A continuación, presentamos la propuesta del Plan Estratégico de la organización.

\subsection{Descripción de la entidad}

Casa Reflector nace en 2011 con la finalidad de realizar propuestas teatrales y de investigación. En 2015, luego de un cambio de socios la empresa toma un nuevo rumbo que la lleva a desarrollar proyectos híbridos en sus tres áreas de trabajo, así se decide crear una Fundación y conservar la empresa S.A.S. A inicios de 2020 la empresa se estructuró ordenando al interior los flujos de trabajo, así las actividades teatrales y relacionadas con educación quedan a cargo de la Fundación y las actividades de creación gráfica, audiovisual, editorial y de merchandising quedan como actividades de la empresa S.A.S. 


\subsection{Misión}

Casa Reflector busca hacer entretenida y dinámica la comprensión y aprendizaje de diversos temas mediante experiencias que involucren recursos artísticos como cómics, infografías, vídeo y puestas en escena (historia viva y sketches).

\subsection{Visión}

Tener un público cautivo que aprenda mediante las experiencias que desarrolla la compañía, así como redes de trabajo y empresas que se interesen en generar y financiar este tipo de propuestas logrando la sostenibilidad de la empresa, la creación de empleos directos e indirectos, así como el beneficio conjunto de comunidades y empresas financiadoras.

\subsection{Filosofía corporativa}

\subsubsection{Principio}

Casa Reflector cree que el arte, la combinación de lenguajes y de recursos artísticos, así como el trabajo riguroso, pueden hacer del aprendizaje un proceso placentero, ágil y efectivo.

\subsubsection{Marco ético}

Casa Reflector, mediante sus acciones y decisiones, propende al desarrollo del conocimiento, el arte, la creatividad, y la participación entre las comunidades con el trabajo adelantado.

\subsubsection{Campo de acción}

Trabajamos desde las siguientes áreas:

- Trabajos en diversos lenguajes artísticos principalmente en creación gráfica, audiovisual y artes vivas relacionándolas entre sí.

- Propuestas artísticas que combinan herramientas digitales, web y tecnológicas.

- Investigación teórica apoyada en la consulta y guía de expertos en los temas 
abordados para, a partir de esta investigación y tutoría, crear las experiencias.

- Relaciones entre empresas, comunidades beneficiarias, especialistas y artistas por intermedio de las experiencias adelantadas.

\subsubsection{Grupos de interés}

Establecemos relaciones con varios grupos:

- Comunidades sean estudiantes, turistas, visitantes de la ciudad, residentes de poblaciones o barrios específicos o personas interesadas en profundizar ciertas áreas del conocimiento.

- Artistas o profesionales que apoyen a los socios en sus creaciones.

- Empresas, ONG, y estamentos del gobierno para la financiación de las experiencias.

- Socios de la empresa.

- Medios de comunicación.

\subsubsection{Objetivos organizacionales}

- Conceptualizar, crear, y exhibir materiales para generar experiencias formativas que faciliten la comprensión de diversos conceptos de una manera entretenida y ágil.

- Trazar para cada una de las experiencias un objetivo de impacto social correspondiente al tema abordado. Un ejemplo de este propósito es el rescate del patrimonio inmaterial y la instrucción en buenas prácticas ambientales.

- Acopiar la información necesaria para desarrollar un banco de información que le permita a la entidad conservar las experiencias y en la media de lo posible tenerlas habilitadas para el disfrute del público.

- Establecer relaciones de trabajo duraderas con empresas que se interesen en el desarrollo de experiencias.

- Generar estrategias que permitan la sostenibilidad de la empresa. 


\subsection{Operacionalización}

\subsubsection{Alcance de la acción}

Casa Reflector actuará como:

- Creadora de contenidos artísticos.

- Creadora de experiencias artísticas y educativas abordando diferentes temas.

- Creadora de un banco de almacenamiento de experiencias desarrolladas por la empresa.

- Promotora de hibridación y mezcla de contenidos artísticos.

- Gestora de proyectos relacionados con arte, cultura y pedagogía.

- Formadora de herramientas lúdicas y educativas desde las artes.

\subsubsection{Modelo de intervención}

Nuestra aproximación a las comunidades dependerá del diseño de cada experiencia; buscaremos tener presencia tanto virtual como presencial para afianzar los contenidos, permitiendo la retroalimentación y evaluación de los participantes.

Este último aspecto es muy importante porque permite conocer la consolidación del proyecto entre el público: para ello se habilitarán los canales idóneos en cada situación. Es fundamental que esta socialización sea realizada de manera amplia conjuntamente con los expertos y las empresas promotoras.

\subsubsection{Presencia territorial}

Buscamos que las experiencias creadas por Casa Reflector incluyan un plan de socialización con un conjunto de actividades estructuradas sinérgicamente tales como: presencia en redes sociales, transmisión por internet, temporadas, giras o réplicas en diferentes sectores de la ciudad de Bogotá, e incluso en diversas ciudades del país. 


\subsection{Medición}

Para medir, evaluar y recomponer -si es preciso- este plan estratégico, establecimos unos indicadores cuantitativos a partir de los objetivos organizacionales establecidos:

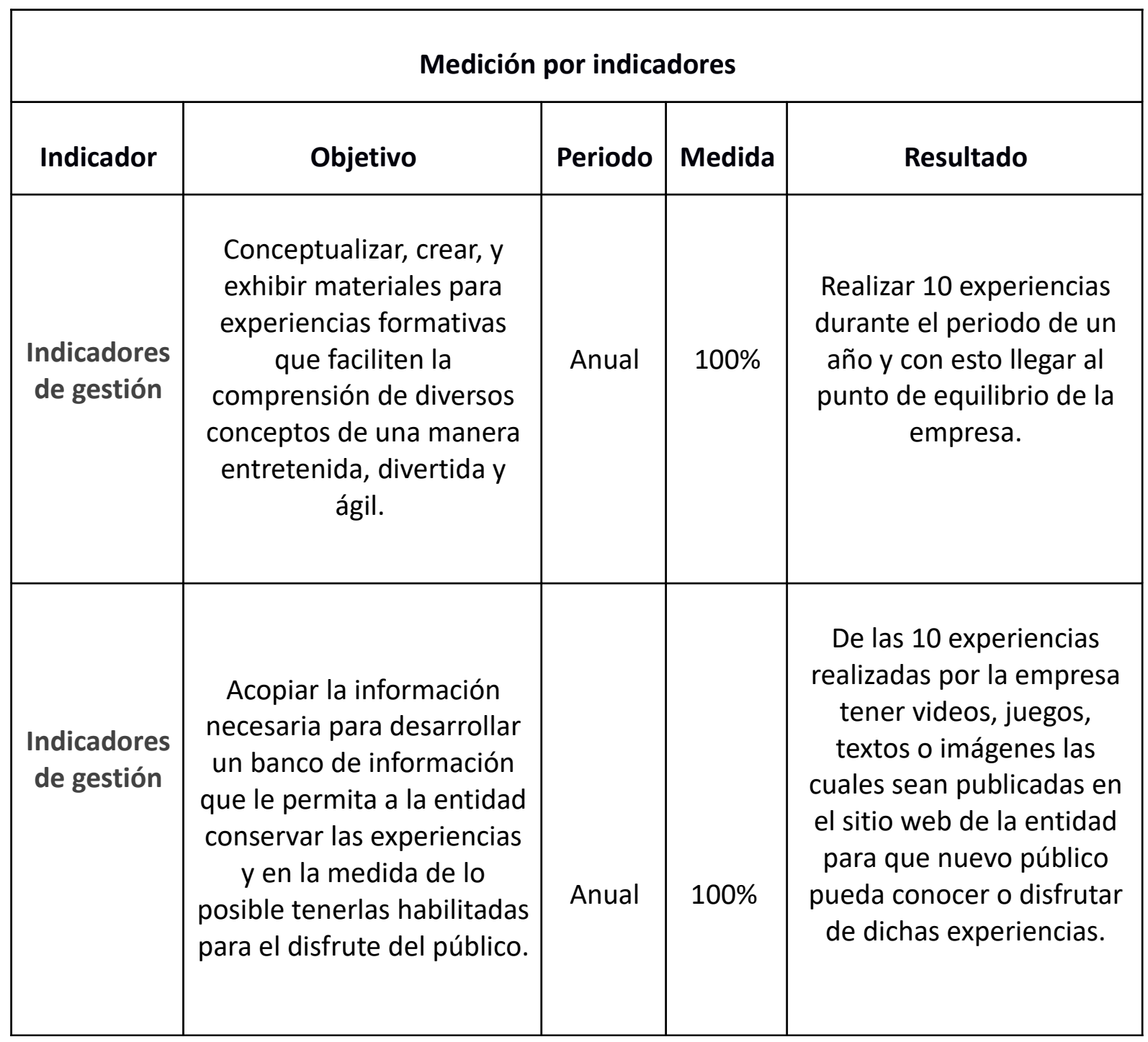




\begin{tabular}{|c|c|c|c|c|}
\hline $\begin{array}{c}\text { Indicadores } \\
\text { de } \\
\text { resultados }\end{array}$ & $\begin{array}{c}\text { Acopiar la información } \\
\text { necesaria para desarrollar } \\
\text { un banco de información } \\
\text { que le permita a la entidad } \\
\text { conservar las experiencias } \\
\text { y de ser posible tenerlas } \\
\text { habilitadas para el disfrute } \\
\text { del público. }\end{array}$ & Anual & $100 \%$ & $\begin{array}{c}\text { Propiciar nuevas relaciones } \\
\text { laborales para la empresa } \\
\text { a través del uso de este } \\
\text { banco de experiencias a } \\
\text { manera de catálogo. }\end{array}$ \\
\hline \multicolumn{5}{|c|}{ Medición por indicadores } \\
\hline $\begin{array}{l}\text { Indicadores } \\
\text { de gestión }\end{array}$ & $\begin{array}{l}\text { Establecer relaciones de } \\
\text { trabajo duraderas con } \\
\text { empresas que se interesen } \\
\text { en el desarrollo de } \\
\text { experiencias. }\end{array}$ & Anual & $100 \%$ & $\begin{array}{l}\text { Fidelizar clientes mediante } \\
\text { el desarrollo de buenas } \\
\text { experiencias. }\end{array}$ \\
\hline $\begin{array}{c}\text { Indicadores } \\
\text { de } \\
\text { resultados }\end{array}$ & $\begin{array}{c}\text { Generar estrategias que } \\
\text { permitan la sostenibilidad } \\
\text { de la empresa. }\end{array}$ & Anual & $100 \%$ & $\begin{array}{l}\text { Realizar visitas o eventos } \\
\text { con propósitos } \\
\text { comerciales. }\end{array}$ \\
\hline $\begin{array}{l}\text { Indicadores } \\
\text { de } \\
\text { resultados }\end{array}$ & $\begin{array}{l}\text { Generar estrategias que } \\
\text { permitan la sostenibilidad } \\
\text { de la empresa. }\end{array}$ & Anual & $100 \%$ & $\begin{array}{l}\text { Crear piezas de mercadeo } \\
\text { derivadas de las } \\
\text { experiencias que puedan } \\
\text { comercializarse. }\end{array}$ \\
\hline
\end{tabular}




\subsection{DOFA}

FORTALEZAS

- Hemos desarrollado algunas experiencias similares con éxito.

- Somos un equipo interdisciplinario que está capacidad de dar respuesta a propuestas mixtas, híbridas, novedosas.

- Nos gustan e interesan los temas científicos, ambientales, sociales, históricos.

\section{DEBILIDADES}

- No sabemos vender.

- No sabemos como acercarnos y crear lazos con empresas y/o posibles clientes.

- No contamos con músculo económico.

- No tenemos tecnología robusta.

\section{DOFA CASA REFLECTOR}

2.DOFA 1 Casa Reflector S.A.S

Fuente: Elaboración propia. 


\section{OPORTUNIDADES}

- Demanda de estrategias educativas.

- No solo los niños y jóvenes en edad escolar se pueden interesar o convertirse en público objetivo.

- Se pueden crear experiencias destinadas a cada segmento de clientes y enriquecer las perspectivas o trabajo sobre un mismo tema.

- La RSE, que a pesar de no ser obligatoria por legislación es clave para certificación de calidad, descuento de impuestos y good will.

\section{AMENAZAS}

- Muchos colegios y universidad crean sus propios contenidos, estrategias y experiencias educativas.

- No encontrar clientes, o que les parezca muy rara la propuesta, o que no tengan interés en desarrollar este tipo de experiencias.

\section{DOFA CASA REFLECTOR}

3. DOFA 2 Casa Reflector S.A.S

Fuente: Elaboración propia. 


\subsection{Organigrama}

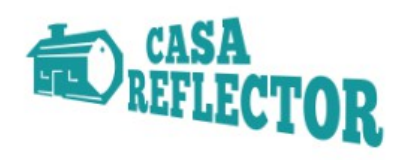

\section{ORGANIGRAMA}

CASA REFLECTOR S.A.S.

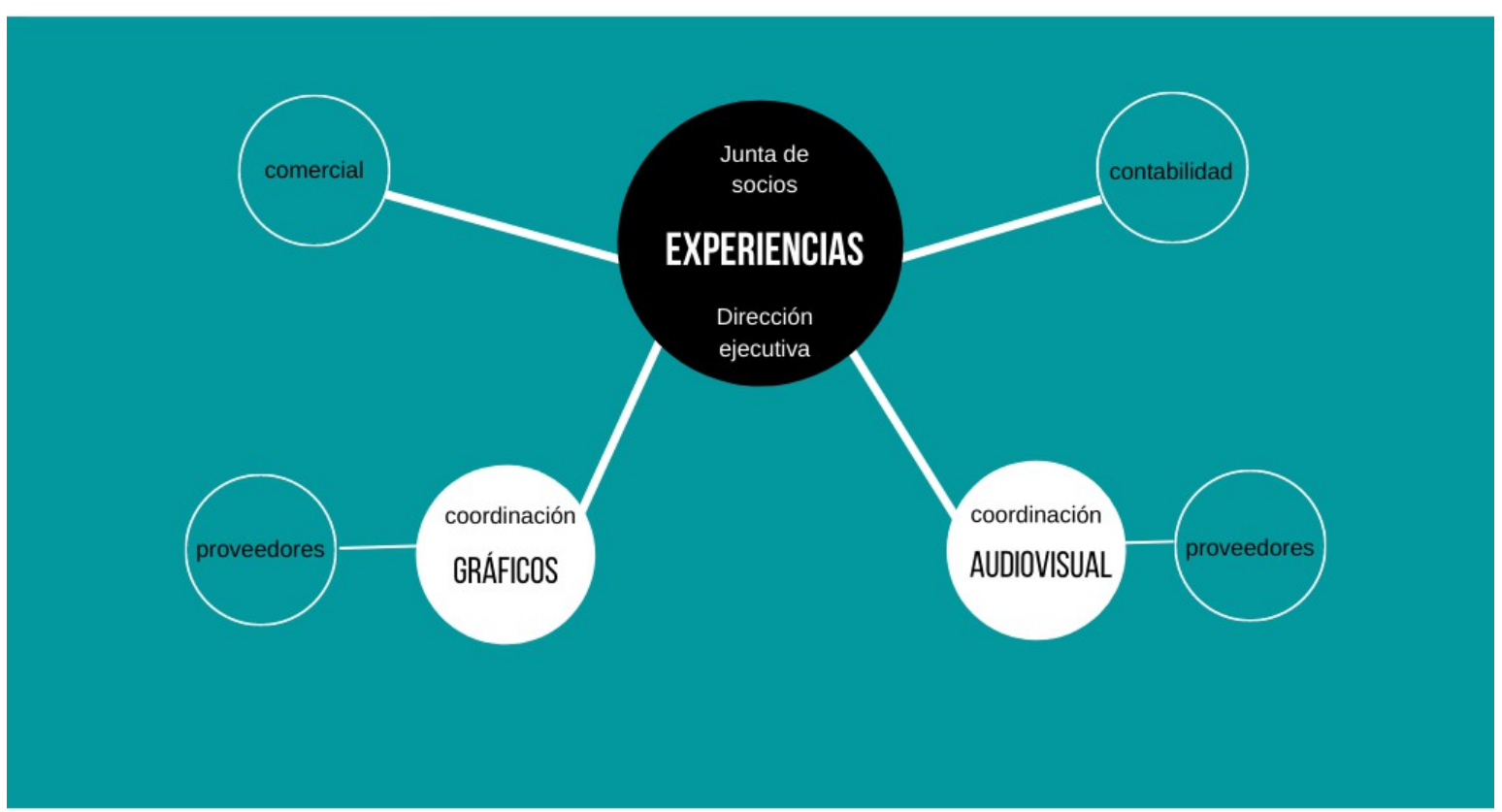

WWW.CASAREFLECTOR.COM

4. Organigrama Casa Reflector S.A.S

Fuente: Elaboración propia. 


\section{Capítulo 2: Modelo de negocio para La mano del oso}

\subsection{Segmentos del mercado}

Cuando se habla de segmentos del mercado se hace referencia a los clientes o público objetivo. Los clientes son el alma de cualquier empresa y, de acuerdo a sus necesidades, cada negocio establece su propio segmento de clientes ofreciendo el producto o servicio que puede atender esas demandas.

Casa Reflector cuenta con un mercado diversificado puesto que para cada proyecto se determina el público específico, y la consecuente ruta de comunicación que se tendrá con cada grupo o empresa, sabemos que podemos tener clientes con intereses temáticos, y eso nos permite inclinar la balanza en la generación de proyectos o contenidos relacionados con temas específicos.

Para el proyecto La mano del oso se ha delimitado como público objetivo a jóvenes y jóvenes adultos entre los 18 a los 35 años en la ciudad de Bogotá.

El público entre los 18 y los 25 es definido como público juvenil, de acuerdo con datos proporcionados por el DANE, es la franja poblacional que más desempleo sufre en el país. Ampliando un poco esa audiencia, consideramos otro público que abarca entre los 25 y los 35 años, audiencia reconocida como adulto joven.

Profundizamos en el conocimiento del público objetivo mediante algunos datos que proporcionan las proyecciones del DANE para 2019:

La ciudad de Bogotá cuenta con el $17 \%$ de la población nacional, aproximadamente 8.181.047 habitantes. De esta cifra, el $48.5 \%$ de la población es masculina y el $51.5 \%$ es femenina. Como sucede en países considerados desarrollados, Bogotá tendrá una pirámide poblacional regresiva, es decir, tiende al descenso en la natalidad y al envejecimiento continuo de su población; la perspectiva de futuro indica un tendencia a la pérdida del bono demográfico es decir la población está envejeciendo.

La población de Bogotá, entre los 20 y los 29 años serían 673.711 hombres y 659.817 mujeres. Entre los 30 y los 39 años se esperaba que fueran 624.523 hombres y 669.670 mujeres. 


\section{Cifras relacionadas con lectura a nivel nacional}

Si bien las cifras que evidencian que en los últimos años el analfabetismo ha disminuido notoriamente en el país es importante destacar que la lectura es aún uno de los hábitos que el colombiano debe ganar.

\section{ALFABETISMO: LEER Y ESCRIBIR}

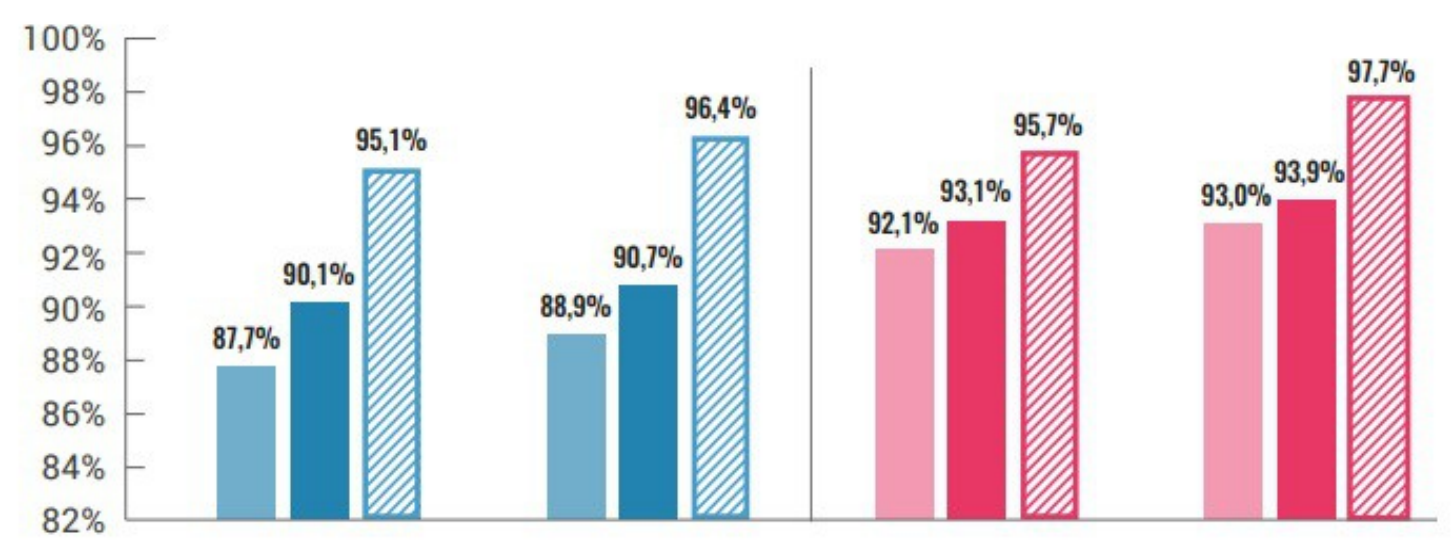

5. Infografía Censo 2018 Total Nacional Colombia. Tomado de: https://www.dane.gov.co/files/censo2018/infografias/info-CNPC-2018total-nal-colombia.pdf

Las cifras relacionadas con el consumo cultural, dan clara cuenta del escenario. Las estadísticas de la encuesta de cultura de 2017 muestran que entre los mayores de 12 años entrevistados que afirmaron saber leer y escribir, quienes más leen son las mujeres con el $54,2 \%$, mientras que solo el $46,0 \%$ de los hombres leyó libros durante el mismo periodo.

En la lectura de libros por rangos de edad se observa que los mayores porcentajes de lectura los presentan las personas de 12 a 25 años y 26 a 40 años con 66,8 \% y 47,4 \%, respectivamente. Los porcentajes más bajos se registraron en los rangos entre 41 a 64 años $(40,6 \%)$ y 65 años y más $(37,9 \%)$.

El promedio de libros leídos por parte de las personas con 12 años o más, que afirmaron saber leer y escribir, y que leyeron libros durante el año 2017 (población lectora), corresponde 4,2. El promedio ha mejorado, aún debe crecer más. 
Gráfico 5. Porcentaje de personas de 12 años y más que leyeron libros Cabeceras municipales

2017

\begin{tabular}{lll}
\hline \multicolumn{2}{c}{ Lectura } & \\
\hline Lectura de Libros & & \\
\hline
\end{tabular}

Fuente: DANE, ECC

Población de referencia: total de personas de 12 años y más que saben leer y escribir ( 29.543 miles). Corresponde a las personas que respondieron con un sí a la pregunta ¿Sabe leer y escribir?

6. Boletín Técnico de la Encuesta de Consumo Cultural de 2017. DANE. Tomado de: https://www.dane.gov.co/files/investigaciones/eccultulral/bole ecc 2017.pdf

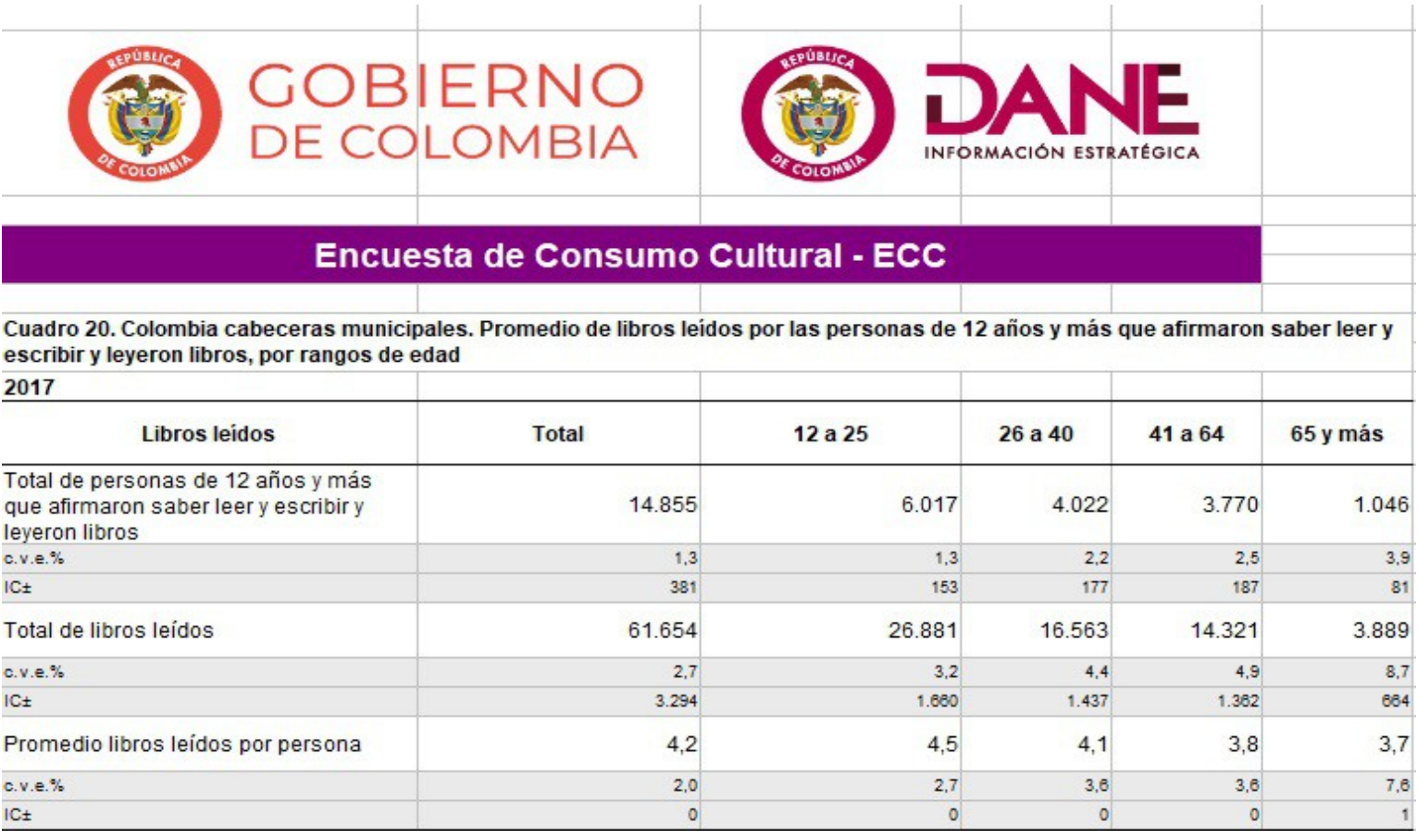

7. Resultados de la Encuesta de Consumo Cultural de 2017. DANE. Tomado de: https://www.dane.gov.co/index.php/estadisticas-por-tema/cultura/consumo-cultural 
En cuanto a preferencias de lectura entre revistas y libros, el DANE proporciona las siguientes cifras: el $44,1 \%$ de las personas consultadas leyó revistas. Por rangos de edad se observa: de 12 a 25 años son los que menos leen con un $37,2 \%$, de 26 a 40 años son quienes tienen mejor promedio de lectura con $48,4 \%$, de 41 a 64 años tienen un $47,7 \%$ y los de 65 años y más, cuentan con un 40,8\%.

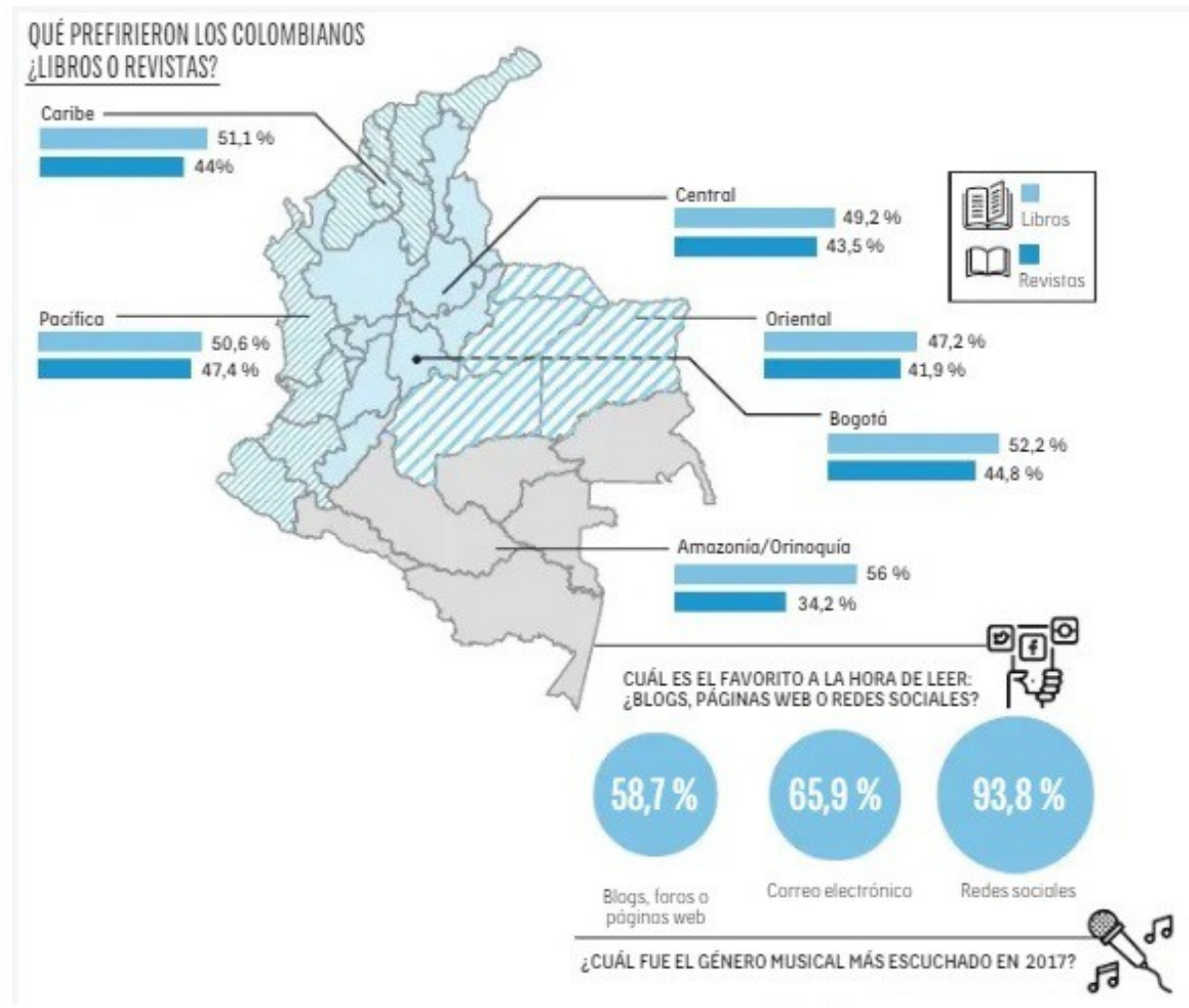

8. Estadísticas sobre consumo cultural de los colombianos en el 2017. Diario El Tiempo. Tomado de: https://www.eltiempo.com/cultura/musica-y-libros/estadisticas-sobre-el-consumo-cultural-de-los-colombianos-en-el$\underline{2017-318372}$

A manera de conclusión podemos determinar que el público seleccionado al ser el que mayores promedios de lectura tiene, puede interesarse en la lectura de la novela gráfica.

Otro dato importante es que los entrevistados prefieren la lectura en redes sociales y sitios web lo que nos indica que la idea de tener el libro impreso y un complemento digital que se muestre mediante medios de comunicación online y redes sociales es positiva. 


\section{Resultados encuesta novela gráfica}

De igual forma, para acércanos más al público objetivo realizamos una encuesta abierta por redes sociales encaminada principalmente a determinar la estrategia de venta y logramos encontrar un panorama alentador (vale la pena anotar que esto fue antes del COVID-19).

El muestreo fue tomado a 59 personas de diferentes procedencias, todos colombianos, residentes en el país principalmente en Bogotá. El 30,5 \% es decir 18 personas, tienen entre 20 y 30 años, el 52,5 \% que corresponde a 31 personas tienen entre 30 y 40 años, y solo 10 personas, el equivalente al 16,9 \% -de las personas que contestaron la encuestatienen entre 40 y 50 años.

La valoración de la encuesta nos permite concluir que al momento de tener la novela gráfica lista podemos contar con personas interesadas en comprar el texto, de igual forma los resultados señalaron el doble riesgo de llevar a cabo la preventa de una ópera prima, así como la falta de conocimiento y participación por parte del público en estrategias de financiación colectiva como el crowdfunding.

\section{¿Compraria una novela gráfica?}

59 respuestas

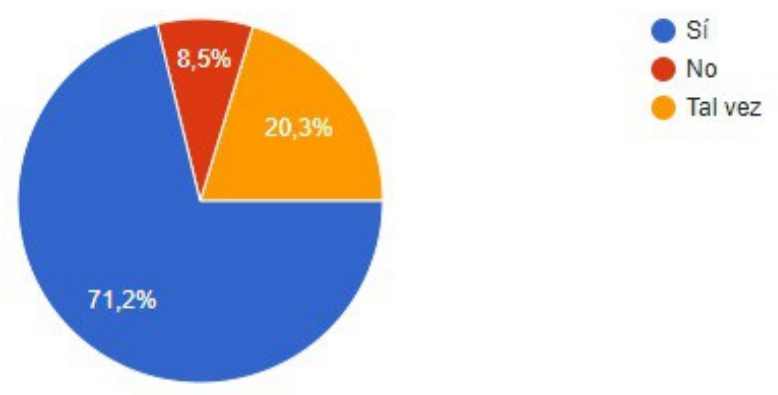

9. Resultados encuesta novela gráfica. Fuente: Elaboración propia. 
Compraria una novela gráfica con un costo entre $\$ 60.000$ y $\$ 80.000$

58 respuestas

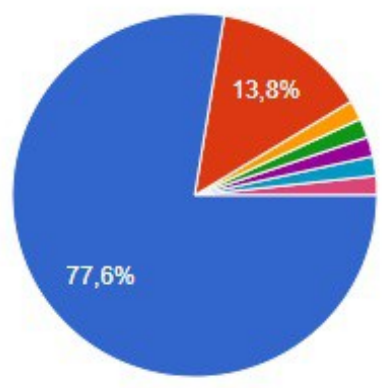

Sí

No

Realmente, no sé

- Depende de la calidad de la ilustración, la historia, etc.; o de la extensión

Si el precio frente a lo que es el producto merece si lo haría

Depende de otros factores como calidad, extensión, tipo de impresión...

Depende. Tiene que convencerme vis...

10. Resultados encuesta novela gráfica. Fuente: Elaboración propia.

¿Ha participado en campañas crowdfunding?

59 respuestas

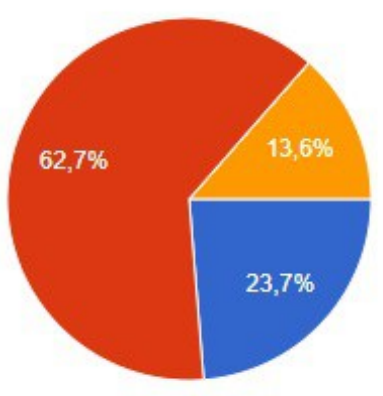

Sí

No

No sé que es crowdfunding

11. Resultados encuesta novela gráfica. Fuente: Elaboración propia. 
Usted compraria un libro "en preventa", conociendo solo con el primer capitulo de la obra.

57 respuestas
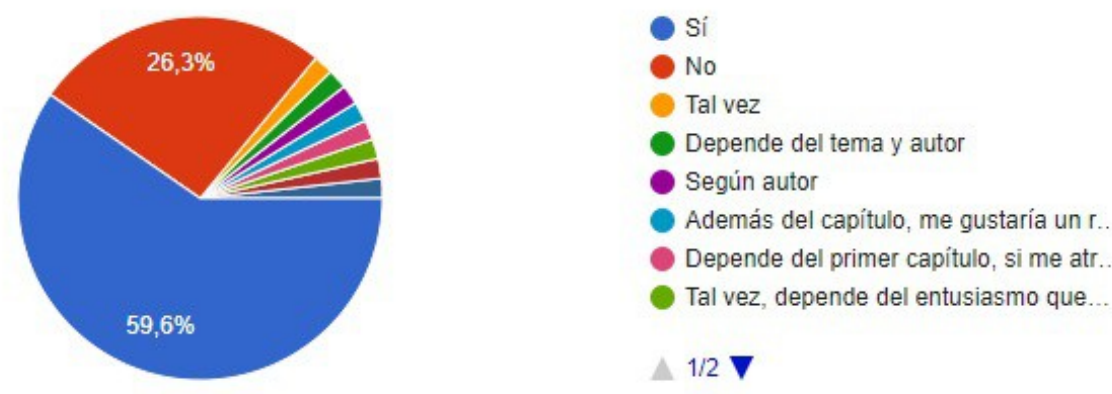

12. Resultados encuesta novela gráfica. Fuente: Elaboración propia.

Para el proyecto La mano del oso, sabemos que el público determinado es amplio por lo tanto buscamos llegar a ellos por diferentes medios. Uno de ellos, se abre mediante las ONG y fundaciones que se interesan en temas de medioambiente a través de sus actividades educativas, así como las cooperativas y las oficinas gubernamentales que trabajen alrededor del medioambiente y puedan apoyar en la divulgación del proyecto. Otro canal a explorar lo encontramos en los programas universitarios relacionados al tema como Biología, Veterinaria, Ecología y/o Comunicaciones. Así mismo, buscamos atraer al público general por medio de las publicaciones en redes sociales y medios de comunicación.

Teniendo en consideración la estrategia de ampliación a redes sociales y medios de comunicación del proyecto, resulta importante anotar que el $74 \%$ de los habitantes de Bogotá cuenta con internet en sus hogares. Y que el 92,5\% de los jóvenes entre los 12 y 25 años usa internet mientras el 59,8 \% de los adultos lo hace. Estos son datos tomados del diario El Tiempo, en artículos que resumen los resultados de la encuesta de consumos culturales de 2017.

Se reconocen como clientes importantes a aquellos que podemos fidelizar o convertir en aliados como es el caso del Santuario del Oso de Anteojos que se perfila como posible cliente interesado en la propagación de este mensaje. 


\subsection{Propuestas de valor}

Una propuesta de valor es el factor que hace que un cliente se incline por una propuesta o proveedor, esta invitación debe crear interés en el segmento de mercado que se busca atender, gracias a una mezcla específica de elementos que pueden ser cuantitativos y cualitativos.

A continuación, enumeramos algunos aspectos que tenemos en cuenta al momento de crear y desarrollar los proyectos en Casa Reflector y que hacen parte de la propuesta de valor.

- Personalización: Cada proyecto es diferente, si bien contamos con propuestas que en algunas oportunidades retoman elementos cada una de las experiencias cuenta es individual y exclusiva.

- Reputación: Después de cinco años de trabajo y el desarrollo de algunas experiencias con resultados positivos, consideramos que la empresa se muestra ante los ojos de los clientes con seriedad y un trabajo de buena calidad.

- Diseño: Trabajamos en desarrollar propuestas atractivas desde el tema hasta el desarrollo estético.

- Comodidad: Buscamos dar las mayores facilidades para los clientes, en cuanto a precios y formas de pago.

Estos elementos son transversales a los diferentes proyectos realizados por la empresa.

Así mismo, pensando en las necesidades de los clientes, patrocinadores o aliados y en la audiencia objetivo del proyecto La mano del oso, se creó una propuesta para cada uno de ellos, desarrollada en un esquema de canvas de propuesta de valor, que permite visualizar las necesidades o problemas del segmento, las tareas o trabajo que debe llevar a cabo ese nicho y el alivio o beneficio que recibe con la propuesta.

Este esquema está pensado desde el escenario de empresas financiadoras y público beneficiario del contenido. 
A continuación, incluimos el canvas de propuesta de valor para los diferentes segmentos atendidos:

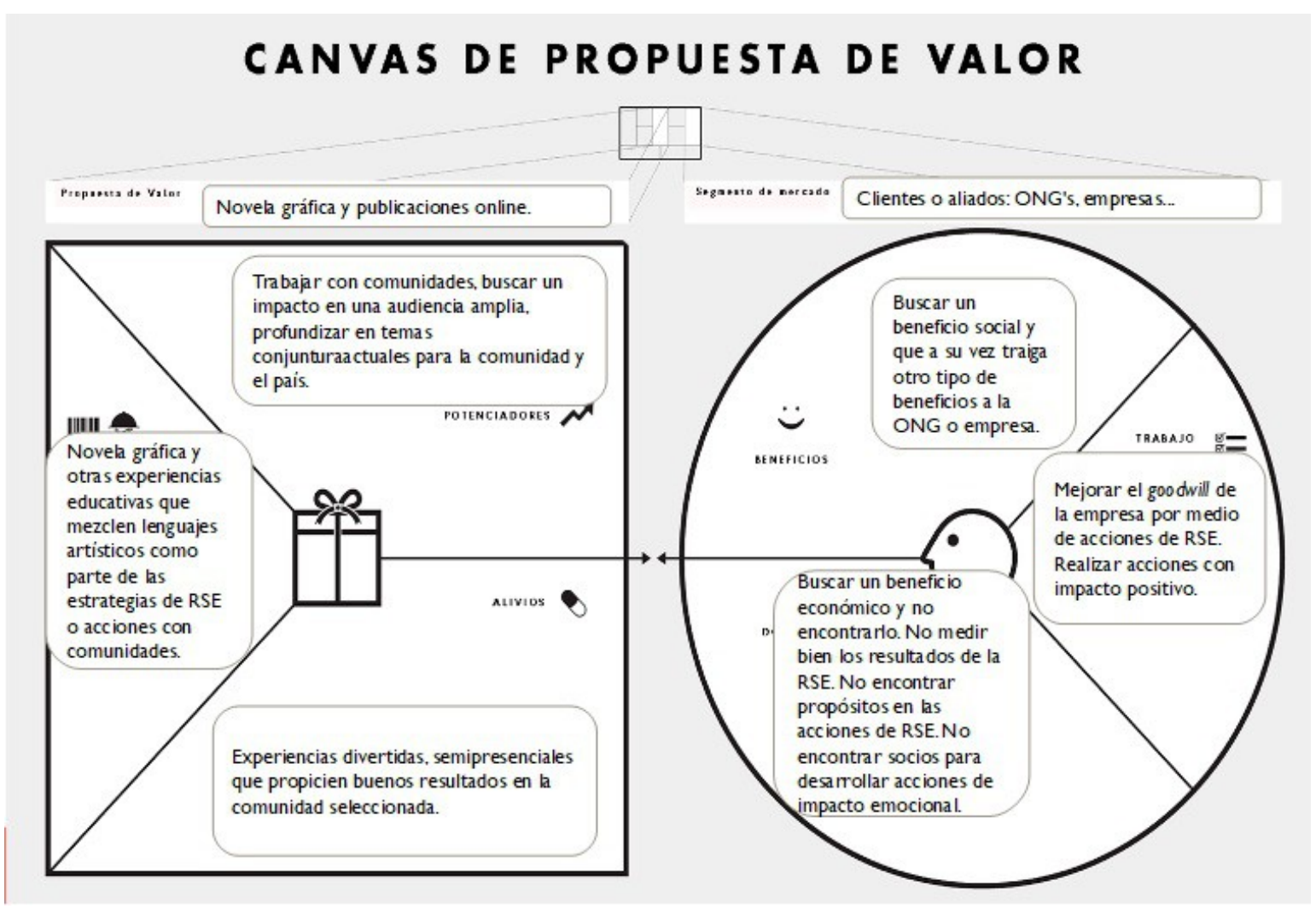

13. Canvas propuesta de valor para empresa u ONG aliadas o patrocinadoras. Fuente: Elaboración propia. 


\section{CANVAS DE PROPUESTA DE VALOR}

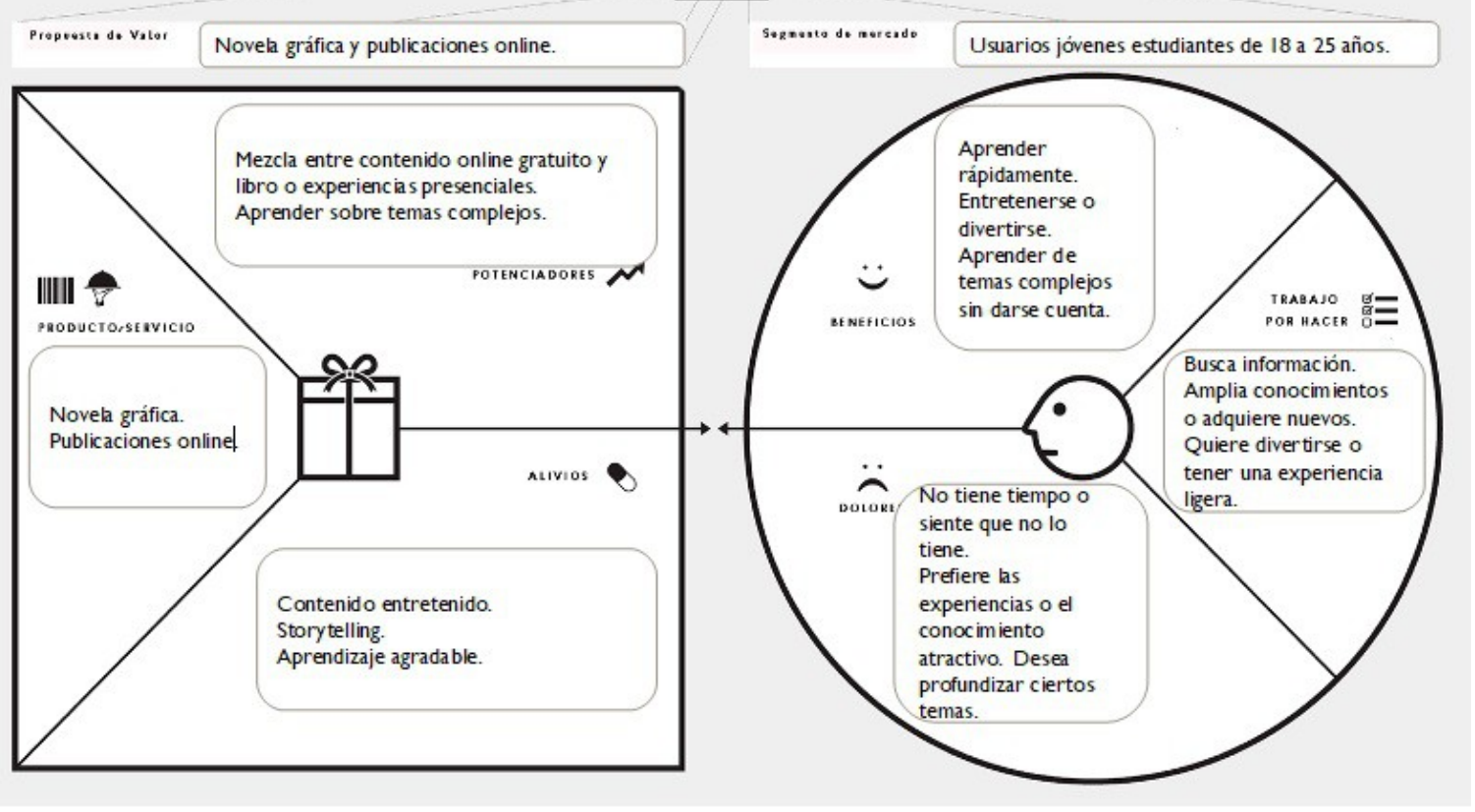

14. Canvas propuesta de valor para usuarios jóvenes de 18 a 25 años.

Fuente: Elaboración propia. 


\section{CANVAS DE PROPUESTA DE VALOR}

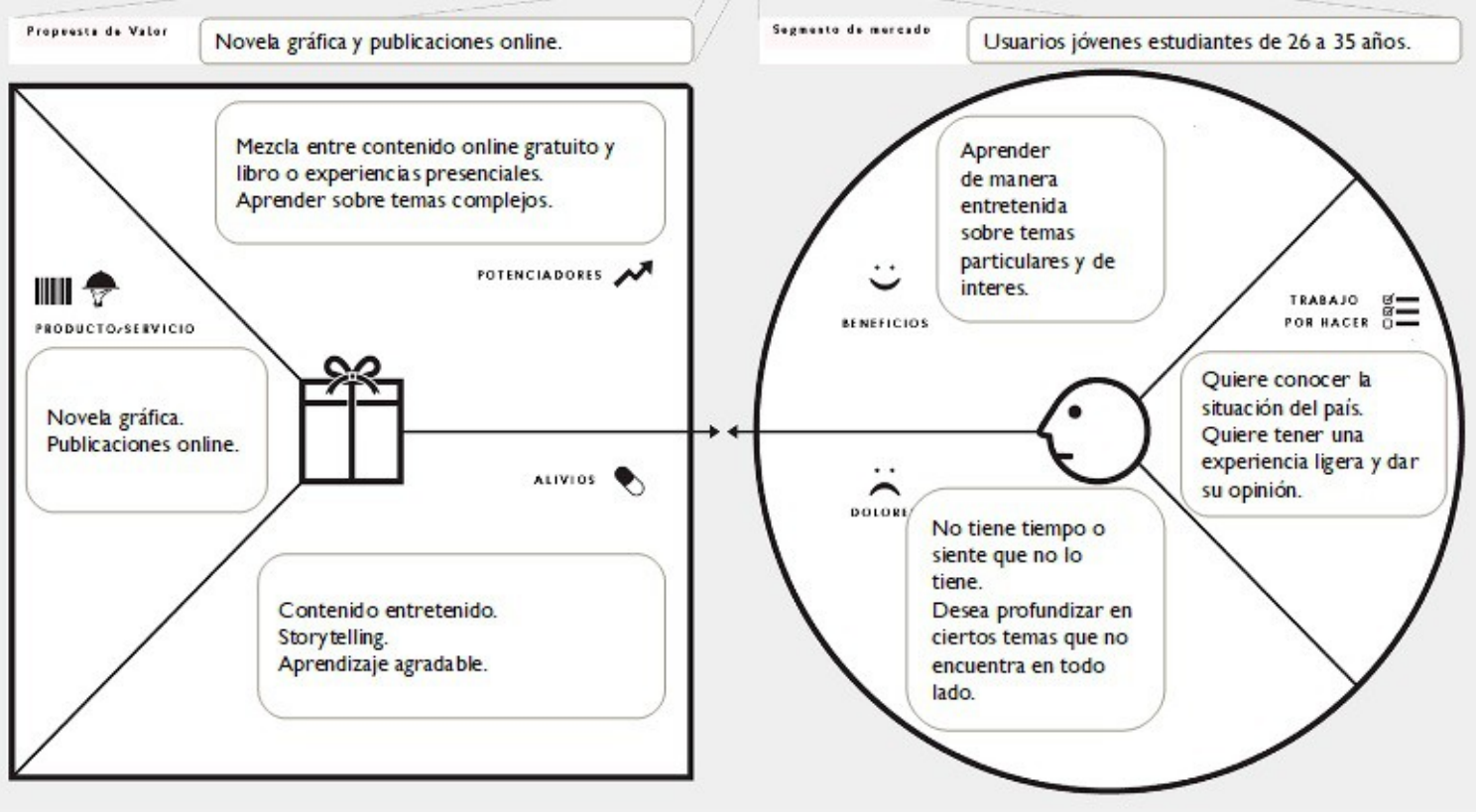

15. Canvas propuesta de valor para usuarios jóvenes entre 26 y 35 años. Fuente: Elaboración propia. 
Una de las propuestas de diferenciación de la empresa consiste en alejarnos de ofrecer servicios estandarizados y amplios como hacer videos, cómics o piezas escénicas, buscamos presentar al cliente las experiencias que hemos realizado y así trabajar con él, en el desarrollo de nuevas propuestas adaptadas a sus objetivos, sin perder de vista la audiencia beneficiaria de cada proyecto.

\subsection{Canales}

Los canales de comunicación, distribución y venta establecen el contacto entre los clientes y la empresa, estos canales tienen como función básica:

- Dar a conocer a los clientes los productos o servicios de la empresa.

- Proporcionar o llevar hasta los clientes la propuesta de valor.

- Permitir que los clientes compren los productos o servicios.

- Ofrecer a los clientes servicios posventa.

Por comunicación externa se comprende el conjunto de acciones que permiten difundir las actividades de la empresa, mejorando su imagen de marca y logrando vínculos con los diversos grupos de interés, sean estos consumidores o clientes, proveedores, socios, aliados o la sociedad en general. Los canales de comunicación pueden ser varios entre los más habituales están el contacto telefónico, las redes sociales, el correo electrónico, los boletines sean semanales o mensuales, los comunicados de prensa.

Por distribución se entiende que los productos o servicios estén disponibles para el público objetivo en el lugar indicado, en la cantidad precisa, en las condiciones adecuadas y en el momento oportuno.

$Y$ por venta efectiva entendemos el pago por un producto o servicio creado y/o proporcionado por la empresa.

Casa Reflector tiene canales de comunicación propios como el sitio web (www.casareflector.com) también redes sociales y el portafolio (que lo pueden encontrar entre los anexos, se ha elaborado dos documentos: el histórico de la empresa y el manual de experiencias Casa Reflector que da cuenta -por medio del ejemplo- de la propuesta) que se envía o lleva de manera física a posibles clientes. El sitio web recibe actualizaciones breves de manera permanente, de acuerdo a las actividades a realizar. A continuación, se muestran algunos apartes: 


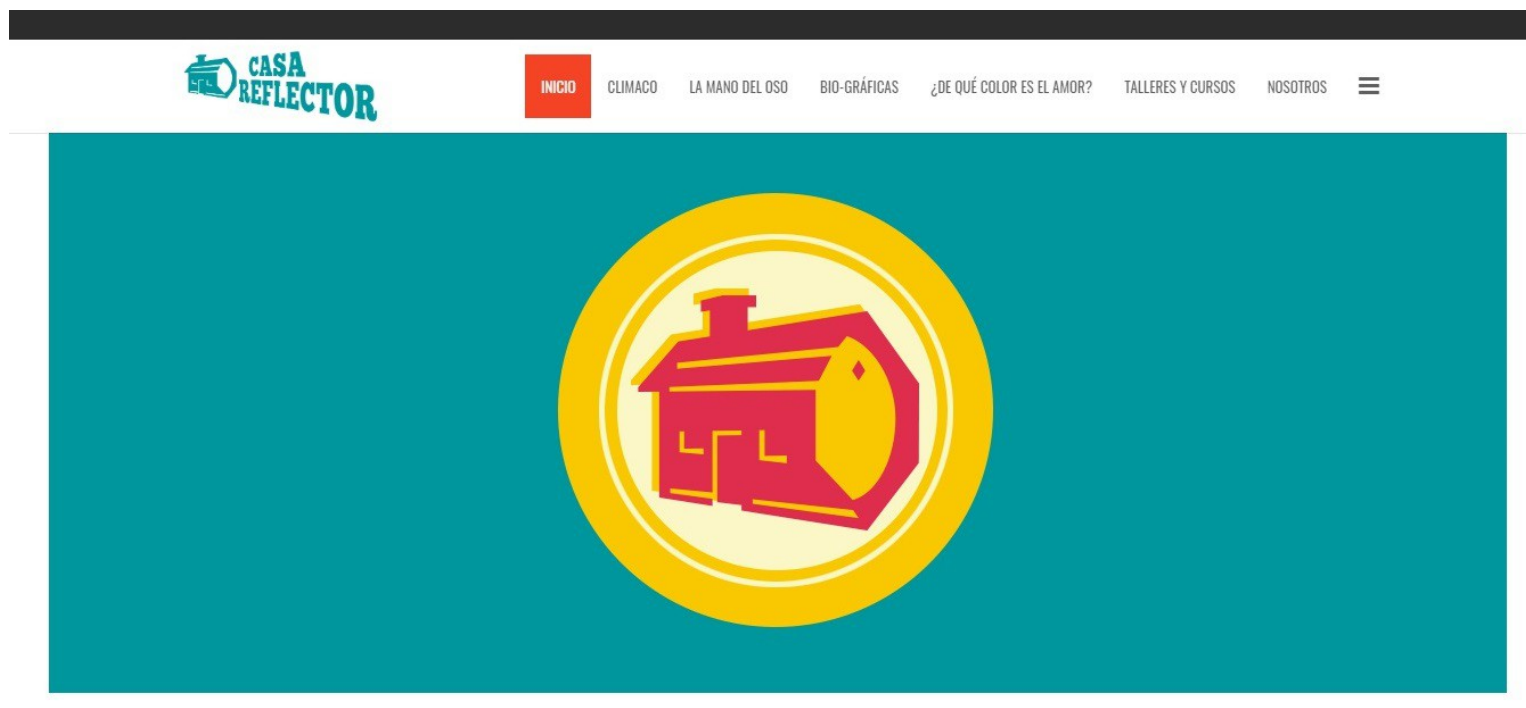

16. Sitio web Casa Reflector 1. Tomada de: www.casareflector.com

$$
\text { 亶 RARARETOR }
$$

incio cumaco lamano del oso bi0-gráflcas zonoúćcolor es elamor?

\section{OTROS TALLERES REALIZADOS}

Taller de dibujo y cómic "Cómics por el cambio climático". 2016

Taller intensivo de pintura mural y de gran formato. 2016.

Taller de teatro "El propio clown". 2017

Taller de juegos teatrales para niños. 2017.

Taller de teatro "El texto en el teatro, material y objetivo del actor". 2017

Taller de cómic "Biográficas de personajes poco ilustres". 2018

Taller de iniciación teatral. 2019.

Taller de juegos teatrales para adultos. 2019
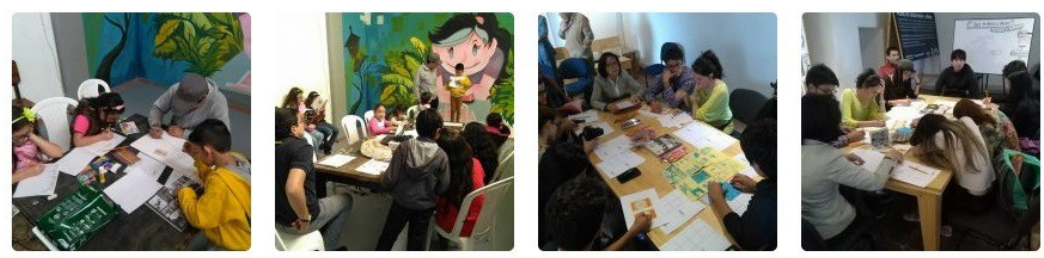

17. Sitio web Casa Reflector 2. Tomada de: https://casareflector.com/talleres-y-cursos/

En las redes sociales, Casa Reflector intenta concentrarse en contenidos propios y/o relacionados con los temas o áreas de trabajo, así como en ser elocuente para quienes siguen las acciones de la empresa. 


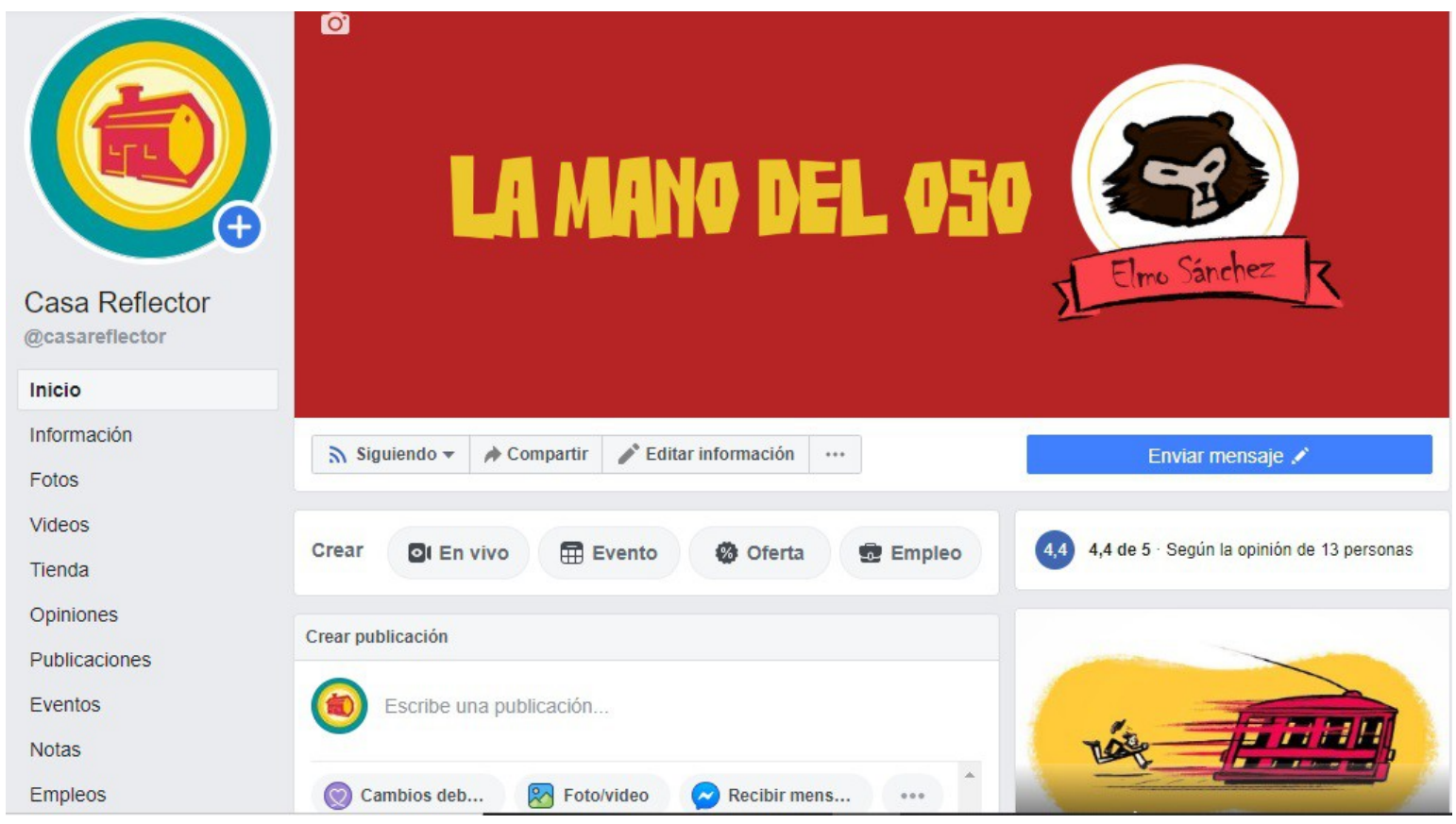

18. Perfil de Casa Reflector en facebook. Tomada de: facebook.com/casareflector

De igual forma para cada experiencia, Casa Reflector busca formas de socialización, distribución y venta intrínsecas al proyecto, y a la temática que aborda.

En el caso de la novela gráfica La mano del oso se cuentan con redes sociales propias que buscan el posicionamiento y la recordación del personaje, así como el desarrollo de un universo narrativo online, donde el visitante encuentre parte de la información en redes sociales y otra en medios de comunicación. Para esto se está buscando generar una alianza con algún medio interesado. Por medio de herramientas narrativas, habituales en los relatos transmedia, se articularán apartes de la novela gráfica impresa con lo publicado en redes sociales y en medios, es decir, que las publicaciones online serán complemento, ampliación y proporcionarán -también- nuevas perspectivas al tema medioambiental, teniendo en cuenta la diversidad de públicos, así como a aquellos que quieran hilar toda la historia, tanto la incluida en el libro y como la del universo online.

Consideramos que el material compartido en redes y en medios debe generar interacción con el público, incluso se puede motivar para que ellos creen frases o situaciones para el personaje. 


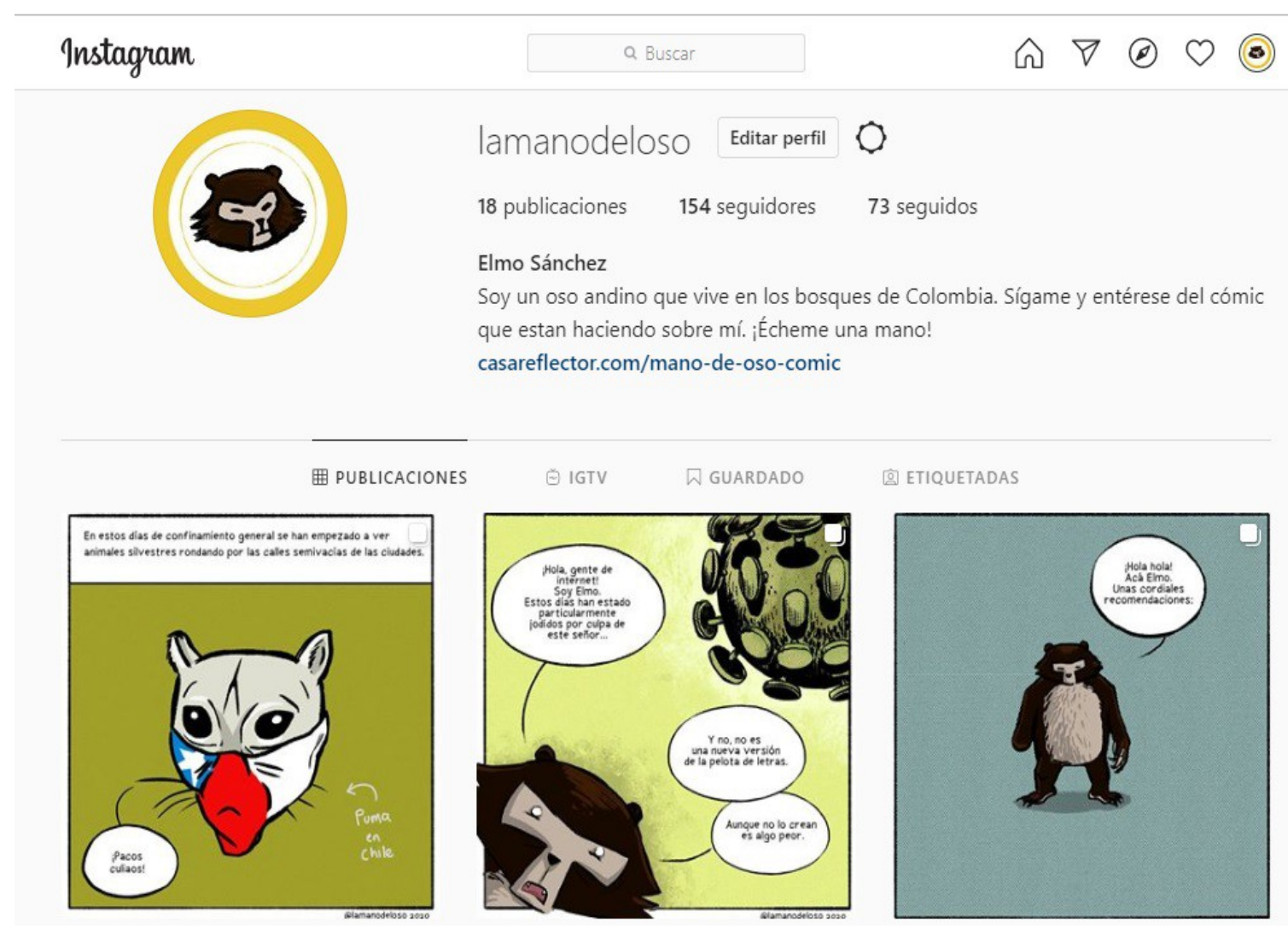

19. Perfil de La mano del oso en IG. Tomada de: https://www.instagram.com/lamanodeloso/ 


\section{$\leftarrow \quad$ Elmo Sánchez}

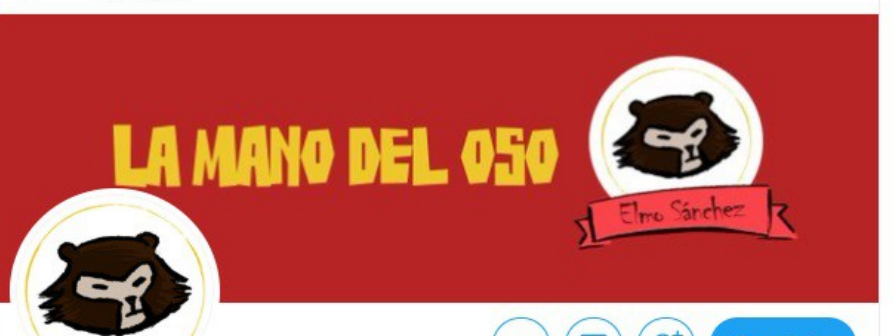

(1) Seguindo

\section{Elmo Sánchez}

@lamanodeloso Segue você

Oso de anteojos. Perdí mi garra y no quiero perder mi hogar. Defiendo el

medioambiente. Protagonista de La mano del oso. \#HaganEIOso \#NoSeDenGarra

Traduzir bio

(2) Colombia $\mathcal{O}$ casareflector.com 푱 Ingressou em julho de 2019

seguindo $52 \quad 24$ seguidores

O. Seguido por Mario Cárdenas, Casa Reflector e outros 7 que você segue

Tweets

Mídia

Curtidas
Q Buscar no Twitter

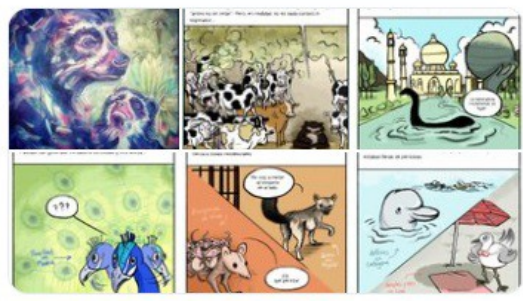

Talvez você curta

.11 @javiersilvaherrera

@javiersilvaher3

Seguir

Bat GOVa ${ }^{\circledR} \cdots$

@GoVaDice

Seguir

Alejandra

@ama_rilla_

Seguir

Mostrar mais

20. Perfil de La mano del oso en TW. Tomada de: https://twitter.com/lamanodeloso

Para la versión impresa del texto, se ha pensado -de acuerdo a las gestiones adelantadasdesarrollar una estrategia que integre tres líneas de comunicación, distribución y venta para obtener los mejores resultados posibles.

1. Consolidar la impresión, distribución y venta mediante financiación obtenida por un convenio, contrato o por compra anticipada de ejemplares con ONG o fundaciones que lo quiera distribuir entre su público objetivo, hay conversaciones adelantadas al respecto con el Santuario del Oso de Anteojos y La Fundación Uraku.

2. Vender ejemplares de manera anticipada al público interesado.

3. Gestionar y firmar una alianza o contrato con una editorial para así tener la línea de distribución tradicional de libros. O que Casa Reflector sea la editorial del proyecto.

De acuerdo a esta estrategia tripartita, se establecen acciones de comunicación, distribución y venta como lo mostramos a continuación: 
Canal

Información

Evaluación

Compra

Entrega

Distribución

Posventa

Patrocinadores, empresas o fundaciones interesadas.

Por medio de las acciones habituales de la empresa o fundación el público beneficiario se entera de la existencia de la novela gráfica. Generalmente los patrocinadores generan dentro de las acciones que llevan a cabo evaluaciones sobre sus actividades y herramientas, eso nos permitirá conocer sus observaciones.

El patrocinador de manera anticipada compra ejemplares de la novela gráfica para sus actividades, para regalarlo o trabajarlo con las comunidades a las que impacta.

Las unidades del libro se entregan de acuerdo a lo pactado en el contrato o convenio.

Canal de distribución indirecto y corto.

Se busca participar en acciones conjuntas con los patrocinados para obtener la retroalimentación necesaria y fortalecer el proceso posventa, así como la vinculación a nuevos proyectos o actividades.

Canal

Propio, auto publicación y venta.

Información o canal de comunicación Evaluación

Compra

Entrega

Distribución Posventa

Por medio del sitio web, las redes sociales, el portafolio y el equipo de ventas se lleva a cabo acciones para dar a conocer el trabajo, experiencia y proyectos que puede llevar a cabo Casa Reflector.

Buscar herramientas para generar observaciones y evaluación sobre nuestros proyectos.

El comprador contacta a la empresa para llevar a cabo la compra o firma del contrato o convenio.

Si es un solo ejemplar o algo pequeño se realiza envío a domicilio, si es una entrega grande se coordina transporte y la entrega.

Canal de distribución directo.

Se llama o entabla conversación con los clientes, se busca hacerlos sentir en confianza para generar relaciones más prolongadas y de beneficio mutuo.

Canal

Editor/tienda Canal tradicional de ventas de libros.

Información o El comprador que visita la tienda sea física u online se encuentra con la canal de comunicación Evaluación novela gráfica e información de esta.

El comprador puede evaluar el producto frente a los otros de la tienda, así como dejar sus observaciones frente al servicio y alternativas de 
libros en la tienda.

Compra El cliente interesado en la novela gráfica realiza la compra sea mediante la tienda física o virtual y cancela por cualquiera de las formas de pago habituales.

Entrega Inmediata por medio de compra presencial o por medio de entrega a domicilio.

Distribución Canal de distribución indirecto y largo.

Posventa Limitada, pocos compradores dejan sus observaciones

\subsection{Relaciones con clientes}

Las empresas deben decidir el tipo de relación que llevarán con los segmentos de clientes que atienden, cada segmento puede tener un tipo de relación o canal diferente, incluso en algunos casos las relaciones pueden basarse en los diferentes momentos del proceso de compra como la captación de clientes, la estimulación de compra y la fidelización de clientes.

En Casa Reflector debido al tipo de proyectos que se llevan a cabo generalmente se recurre a la asistencia personalizada, un miembro de la empresa lleva el contacto con el cliente y guía el proceso desde la concepción del proyecto, la evaluación de propuestas, el resultado final y acompaña todo el proceso de cierre de contrato o convenio, así como el correcto desembolso del dinero.

En el caso de La mano del oso, como se vio anteriormente, al contar con unas organizaciones interesadas en apoyar el proyecto, se tiene un contacto de asistencia personalizada como el descrito anteriormente.

Para establecer contacto con la audiencia del libro se usarán diversos canales de comunicación (algunas ideas ya fueron comentadas anteriormente) principalmente se usarán los canales online del proyecto, así como la difusión mediante la presencia digital de entidades amigas, para completar la presencia virtual se propone el desarrollo de publicaciones periódicas se piensan que propicien la participación del público en actividades desde algunas sencillas como preguntas o encuestas, hasta concursos donde sus opiniones o ideas sean la base para el desarrollo de aventuras del protagonista. 


\subsection{Fuentes de ingresos}

Las empresas con múltiples productos o servicios suelen recurrir a diversos mecanismos para establecer sus fuentes de ingresos. En el caso de Casa Reflector, desde 2015 a la fecha la empresa se ha financiado por medio de convocatorias y convenios, sin negar la importancia de las becas, pero también reconociendo su carácter incierto, así como el margen de coproducción que exigen y la falta de apoyo al desarrollo de empresa como tal, se ha procurado generar líneas de negocio para la empresa, que sin perder de vista el objeto de la misma propicien un flujo de caja y de proyectos, que permitan una acción constante.

Con esta intención se crearon los proyectos La mano del oso y el recorrido turístico teatralizado Directo Memoria, generando proyectos que permitieran el posterior desarrollo de iniciativas similares o la ampliación de los mismos favoreciendo la venta de productos a nichos específicos. Luego del desarrollo de la fase piloto y teniendo en consideración la situación actual se decidió priorizar en el desarrollo de la novela gráfica.

En el caso del proyecto La mano del oso hemos encontramos cuatro posibles fuentes de financiación:

1. Convocatorias: Recordar que el proyecto nace como fruto de la convocatoria realizada por la FLIP -Fundación para la Libertad de Prensa- y seguimos buscando otros estímulos en las que podamos participar teniendo en cuenta los parámetros y cronograma del proyecto. Entre los anexos encontrarán el cuadro de convocatorias para novela gráfica que hemos logrado crear.

2. Venta de ejemplares: La venta de ejemplares es fundamental y estamos buscando varios medios para hacerlo realidad.

- Por medios tradicionales, es decir, logrando una distribución convencional llegando al público a través de librerías, para ello se ha entablado contacto y se ha presentado la propuesta a varias casas editoriales.

- De manera auto gestionada, vendiendo a través de medios virtuales, participando en las ferias y eventos que sean posibles para ofrecer y vender la novela gráfica.

-Coordinando la venta anticipada de ejemplares, con las entidades que apoyan el proyecto, esto es fundamental para el proceso auto gestionado, puesto que viabiliza el 
paso a la fase de producción -entendida como impresión- del libro.

3. Patrocinio: Entre las fundaciones o empresas que apoyan el proyecto alguna puede interesarse en invertir recursos, a manera de patrocinio, el objetivo de estos recursos sería ampliar la población beneficiaria del proyecto, asegurando el desarrollo y producción de viñetas para publicar en medios de comunicación online o redes sociales.

4. Venta de material promocional del personaje: Teniendo en consideración la estrategia elaborada, si el personaje logra tener un impacto considerable en el universo online, se proyecta la creación y venta de material promocional, conocido merchandising u objetos promocionales, entre estos se contempla ropa, juguetes, elementos de papelería.

\subsection{Recursos clave}

Cada empresa tiene unos recursos indispensables para el trabajo que realiza, estos recursos pueden ser físicos, económicos, intelectuales, humanos y la empresa puede tenerlos de diversas maneras: alquilados, de su propiedad, en asocio entre los socios o con otras empresas.

En el caso de Casa Reflector, los recursos con los que contamos que son indispensables a nuestra labor, son los recursos humanos, la especificidad de cada uno de los socios se hace indispensable para el desarrollo del objeto que realizamos. Así mismo, contamos con una experiencia individual y colectiva que hace que la empresa brinde productos particulares y con una buena calidad.

Por supuesto, también contamos con recursos intelectuales, es decir, registros de derechos de autor, diseños, creaciones, investigaciones realizadas que son propiedad de la empresa o de cada uno de los socios en particular y que son susceptibles de tornarse como elemento indispensable en el desarrollo de los proyectos.

\subsection{Actividades clave}

Son consideradas actividades clave, las acciones que debe desarrollar una empresa para tener éxito en su labor, en el caso de Casa Reflector siempre realizamos acciones de conceptualización e investigación para los diversos proyectos, así como la búsqueda de la hibridación de lenguajes artísticos. 
De otro lado, resulta de absoluta importancia la gestión e introducción del proyecto y la empresa a otras entidades. Ese acercamiento nos ha mostrado que la empresa, debe ser más fuerte en su área de alianzas y que esto generará un fortalecimiento en su área comercial.

También trabajamos en el robustecimiento de las fases de preproducción, producción y posproducción, determinando las procesos y acciones exactas que tiene cada uno de estos momentos dentro los diferentes proyectos.

\subsection{Asociaciones clave}

Las empresas deben crecer y trabajar en equipo para obtener mejores resultados, así se plantea el tener alianzas o asociaciones con otras entidades sea o no competencia directa, así como con empresas que permitan crear nuevos negocios, y por supuesto, entablar buenas y -ojalá- estrechas relaciones con los proveedores con quienes se puede establecer un beneficio mutuo.

Es importante para Casa Reflector, en el marco del proyecto La mano del oso contar con el apoyo de ONG y fundaciones que trabajando alrededor del medioambiente brinden una base conceptual al desarrollo del mismo, establecer lazos con editoriales facilitará llevar a cabo la labor editorial que resulta un territorio inexplorado para la empresa y, por último, pero no menos importante relacionarse con litografías que con su quehacer formarán parte vital de la cadena de creación del libro que es la apuesta central de esta iniciativa.

Para tal fin, se han creado bases de datos con las empresas que pueden ser aliadas, así como con posibles proveedores, a continuación, encontrarán el mapa de aliados, las bases de datos hacen parte de los anexos. 


\section{MAPA DE ALIADOS}

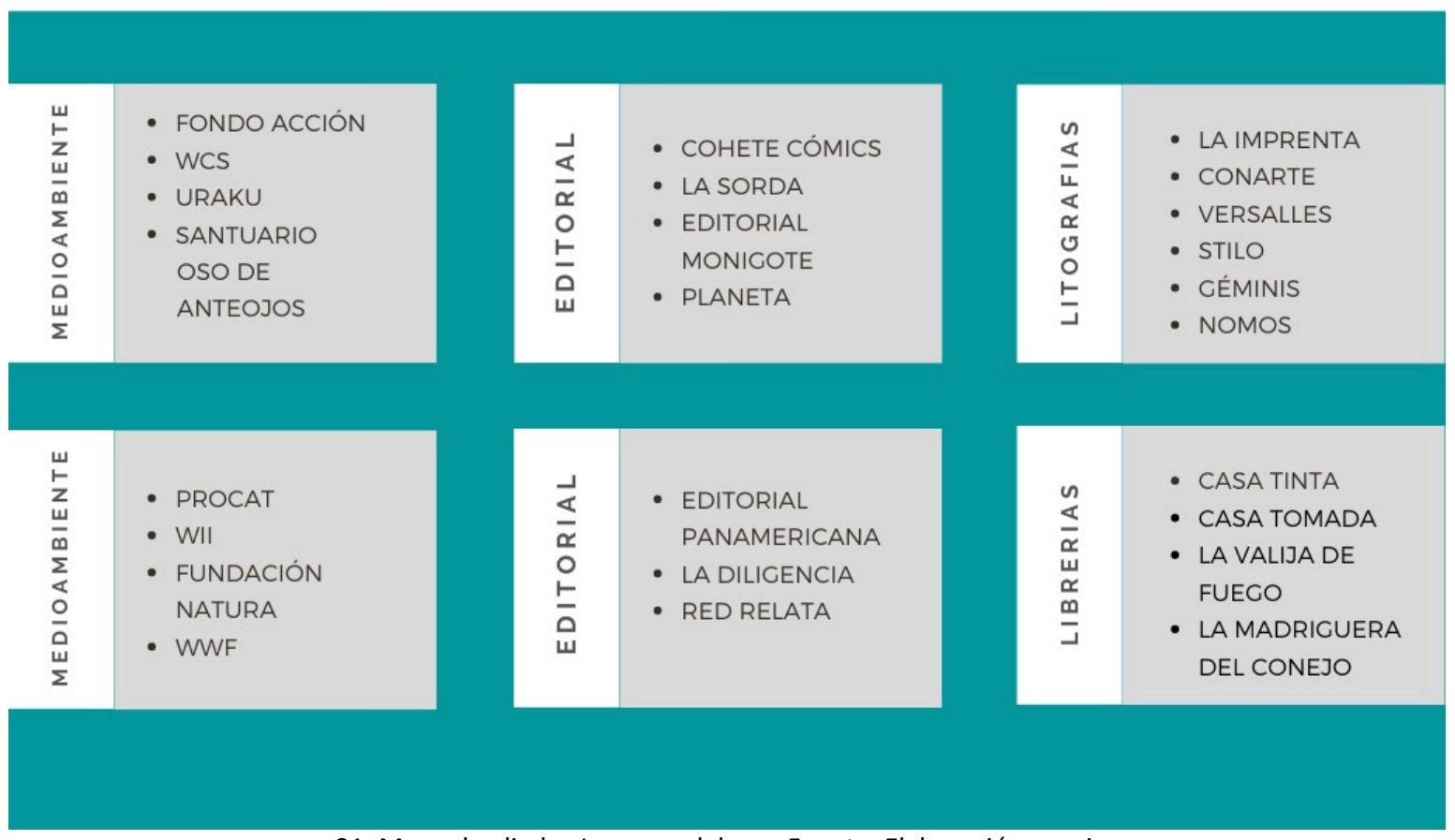

21. Mapa de aliados La mano del oso. Fuente: Elaboración propia.

\subsection{Estructura de costos}

Para consolidar las ventas es importante dar respuesta a dos preguntas ¿qué valor está dispuesto a pagar mi cliente? y ¿cuáles serían las formas de pago de las que dispone?

En Casa Reflector, el establecimiento de precios se da de manera dinámica, es decir cada proyecto tiene precios diferentes, generalmente se elabora un presupuesto y a partir de éste se establece el porcentaje de utilidad. La cotización se presenta al cliente, pasando a una fase de negociación donde se define completamente el proyecto, los costos y la forma de pago.

En el caso de la novela gráfica, para establecer el valor de venta al público se ha tenido en consideración el proceso de creación y elaboración de libros, así como el método usado por las editoriales para este fin. 


\section{Proceso de elaboración de libros}

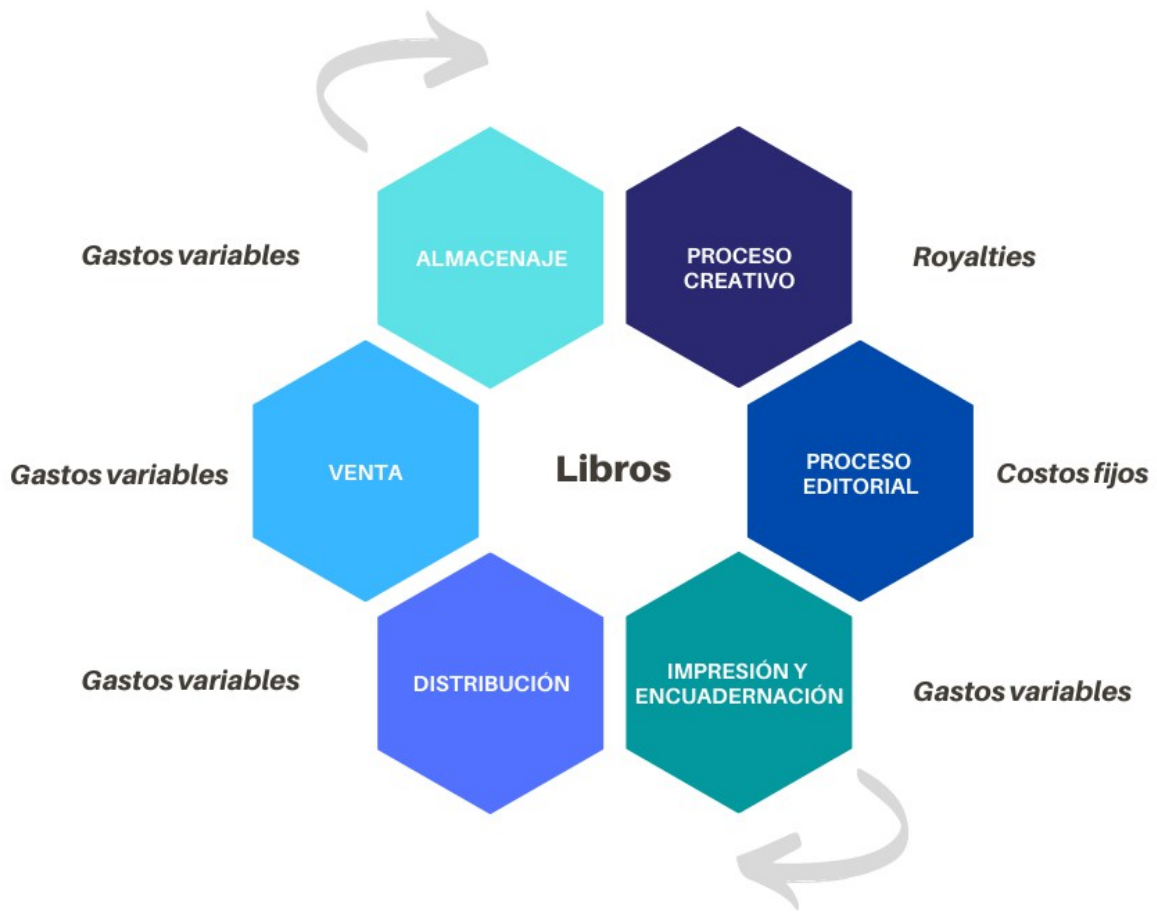

22. Gráfico proceso de elaboración de libros. Fuente: Elaboración propia.

- Los costos fijos:

Estos costos se deben cubrir siempre independiente de la operación de la empresa, en el caso del mercado editorial estableceríamos: costos administrativos, editoriales como la traducción, la corrección (de estilo, ortotipográfica...), diseño editorial, ilustración o fotografías, traducción, ISBN e incluso incluyo una publicidad mínima. 


\begin{tabular}{|l|c|}
\hline Costos operativos & 200.000 \\
\hline Corrección de estilo & 700.000 \\
\hline Diagramación textos + ilustración (asesoría) & 500.000 \\
\hline Dirección o coordinación editorial & 500.000 \\
\hline Ilustración & 2.000 .000 \\
\hline ISBN & 75.000 \\
\hline Publicidad & 500.000 \\
\hline Total & 4.475 .000 \\
\hline
\end{tabular}

- Los gastos variables:

Estos gastos se derivan de la actividad a realizar, del volumen o cantidad de la misma y demás aspectos operacionales. Para el proceso de producción de los libros se pueden establecer como gastos variables la impresión, encuadernación, distribución, almacenamiento.

\begin{tabular}{|l|r|}
\hline Impresión, encuadernación, empaque 500 unidades & 3.147 .550 \\
\hline Publicidad online & 500.000 \\
\hline Total & 3.647 .550 \\
\hline
\end{tabular}

La suma de costos y gastos originará el costo mínimo, que se divide por la cantidad de ejemplares del tiraje dando el costo unitario.

\begin{tabular}{|l|r|}
\hline Total costo mínimo & 8.122 .550 \\
\hline Total costo mínimo unitario & 16.245 \\
\hline
\end{tabular}

Al costo unitario se le suman las regalías, fees, royalties de cada uno de los agentes que intervienen en el proceso como un porcentaje que cubrirá el comprador final y que conformará el precio de venta al público o PVP.

El mercado editorial tiene establecidos incluso algunos porcentajes que son habituales en la operación:

- Autores ganan entre el $8 \%$ y el $12 \%$ de cada ejemplar vendido sobre el PVP.

- Distribuidores alrededor del $30 \%$ de cada ejemplar vendido sobre el PVP.

- Librerías entre el $35 \%$ y el $45 \%$ de cada ejemplar vendido sobre el PVP.

- Editorial entre el $20 \%$ y $25 \%$ de cada ejemplar vendido sobre el PVP.

Es importante tener presente que: 
- Los libros están exentos de iva, pero los gastos de impresión no.

- El tiempo de venta de un libro es extenso y las ventas fluctúan en ese espacio de tiempo.

- El almacenamiento y transporte de libros genera costos que pueden ser altos.

- Se recomienda que el PVP sea el equivalente a mínimo tres veces el valor de costo unitario para cubrir con facilidad todos los porcentajes de regalías.

Mediante la estrategia online se busca que la novela gráfica impacte en el público objetivo y se genere un diálogo alrededor de temas de medioambiente, prolongando la vida del personaje en el tiempo, favoreciendo las ventas por un periodo más amplio de lo habitual.

El presupuesto para obtener el PVP (precio de venta al público) lo encuentran en la carpeta de anexos, así como el canvas del proyecto La mano del oso.

\subsection{Análisis del entorno editorial en Colombia}

A partir de la consulta de diversos informes creados por el CERLALC, el Ministerio de Cultural, Unesco y otras organizaciones, se recogen informaciones que permiten la elaboración de un breve análisis de la situación editorial en el país.

\section{Marco legislativo}

De acuerdo a los artículos 70 y 71 de la Constitución Colombiana se requiere fomentar el acceso a la cultura, en igualdad de oportunidades para todos los colombianos por medio de la educación. La búsqueda del conocimiento y la expresión artística son libres y en los planes de desarrollo económico se deberá incluir el fomento a las ciencias y, en general, a la cultura.

A partir de este contexto, se promulga la ley del libro o ley 98 de 1993 que busca la democratización del libro y su uso como medio principal de transmisión del conocimiento, la cultura y el patrimonio. Esta ley busca estimular la lectura y la producción intelectual -por medio de condiciones editoriales propicias- para convertir al país en un centro editorial, fuerte en exportaciones y en circulación interna, estimulando la distribución y venta de libros, así como la creación de librerías y bibliotecas, en todas las regiones del país. Aunque la ley fue muy buena, el artículo dos hacía una terrible excepción: 
Para los fines de la presente Ley se consideran libros, revistas, folletos, coleccionables seriados, o publicaciones de carácter científico o cultural, los editados, producidos e impresos en la República de Colombia, de autor nacional o extranjero, en base papel o publicados en medios electromagnéticos. Se exceptúan de la definición anterior los horóscopos, fotonovelas, modas, publicaciones pornográficas, tiras cómicas o historietas gráficas y juegos de azar.

(Ley 98, 1993, art. 2)

Así las historietas y cómics se quedaban por fuera de los beneficios de la ley del libro, teniendo que pagar iva y las empresas productoras otros aranceles, encareciendo el producto. Sin embargo, en 2013 la Corte Constitucional aprobó una sentencia que modificó dicha ley, otorgando exenciones tributarias a las comiquitas y novelas gráficas, es decir, actualmente se venden libres de IVA.

Esto, al igual que el aumento de la producción mundial de cómics y el auge de la novela gráfica como formato, ha motivado a la creación y desarrollo de este tipo de obras en Colombia, e incluso al nacimiento de editoriales y sellos que se dedican a este tipo de publicaciones.

\section{Algunas cifras del sector en Colombia}

El análisis elaborado por el CERLALC al sector del libro para 2017, presenta algunos datos reveladores del mercado colombiano:

- El segmento de libros y publicaciones creció un 17,3 \% entre el 2007 y el 2014.

- En el mismo periodo, la producción de libros, diarios, revistas, y otros materiales creció un $112 \%$ así como las importaciones que aumentaron un $183 \%$.

- En 2014, la cifra exportaciones correspondieron a 142 millones de dólares, mientras las importaciones fueron el equivalente a 158 millones de dólares.

El Ministerio de Cultura, mediante el artículo El sector editorial en Colombia: una breve aproximación a sus dinámicas, revela algunas otras cifras interesantes, así como la preocupación del sector por la agremiación, la producción y recopilación de información. En pro de esto trabajan varias entidades y agremiaciones, como la Cámara Colombiana del Libro, la Asociación Colombiana de Librerías Independientes, ACLI, la Red de Editoriales Independientes de Colombia, REIC, la Asociación de Editoriales Universitarias de Colombiana, ASEUC, entre otras. 
También presenta un cuadro comparativo de producción editorial entre los años 2010 y 2014. Dicho cuadro evidencia un crecimiento del mercado entre 2010 y 2012, en 2013 la producción tuvo una reducción considerable, que al parecer obedeció a la situación de Venezuela y la disminución de ventas de libros hacia ese país, en 2014 la producción se repliega un poco más.

Tabla 1. Cuenta Satélite de Cultura. Cuenta de Producción. Actividad de edición de libros. Serie 2010-2014. Valores a precios del año 2005 por encadenamiento. En miles de dólares

\begin{tabular}{lccccc} 
Conceptos & $\mathbf{2 0 1 0}$ & $\mathbf{2 0 1 1}$ & $\mathbf{2 0 1 2}$ & $\mathbf{2 0 1 3}$ & $\mathbf{2 0 1 4}$ \\
\hline 1. Cuenta de producción & & & & & \\
\hline P.1 Producción & 342.904 & 353.627 & 379.658 & 374.788 & 364.226 \\
\hline P.1 Total edición de libros como actividad principal & 280.544 & 292.253 & 316.382 & 292.094 & 260.984 \\
\hline P.11 Edición de libros en EDITORIALES COMERCIALES & 242.383 & 244.627 & 261.134 & 256.392 & 226.016 \\
\hline P.11 Edición de libros en EDITORIALES UNIVERSITARIAS & 38.161 & 47.626 & 55.248 & 35.702 & 34.969 \\
\hline P.11 Producciones secundarias & 62.360 & 61.373 & 63.276 & 82.695 & 103.242 \\
\hline P.2 Consumo intermedio & 182.724 & 182.365 & 194.499 & 164.612 & 175.844 \\
\hline B.1 Valor agregado bruto & 160.181 & 171.261 & 185.159 & 210.176 & 188.381 \\
\hline
\end{tabular}

Fuente: DANE - Ministerio de Cultura. ${ }^{8}$

23. Tabla que muestra la producción de libros El sector editorial en Colombia: una breve aproximación a sus dinámicas. Ministerio de Cultura. Imagen tomada de https://oibc.oei.es/uploads/attachments/43/El sector editorial en Colombia.pdf

En el texto Espacio Iberoamericano del Libro 2018, el estudio adelantando anualmente por el CERLALC que ofrece estadísticas para conocer la situación del sector editorial, se encuentra un gráfico comparativo que abarca desde 2008 hasta 2015, mostrando el desarrollo del mercado y la producción de títulos en Colombia, en el que se puede apreciar el crecimiento del sector en este lapso de tiempo. 
GRÁFICA 34. Producción de títulos frente al desarrollo del mercado en términos de crecimiento real en Colombia (2008-2015)

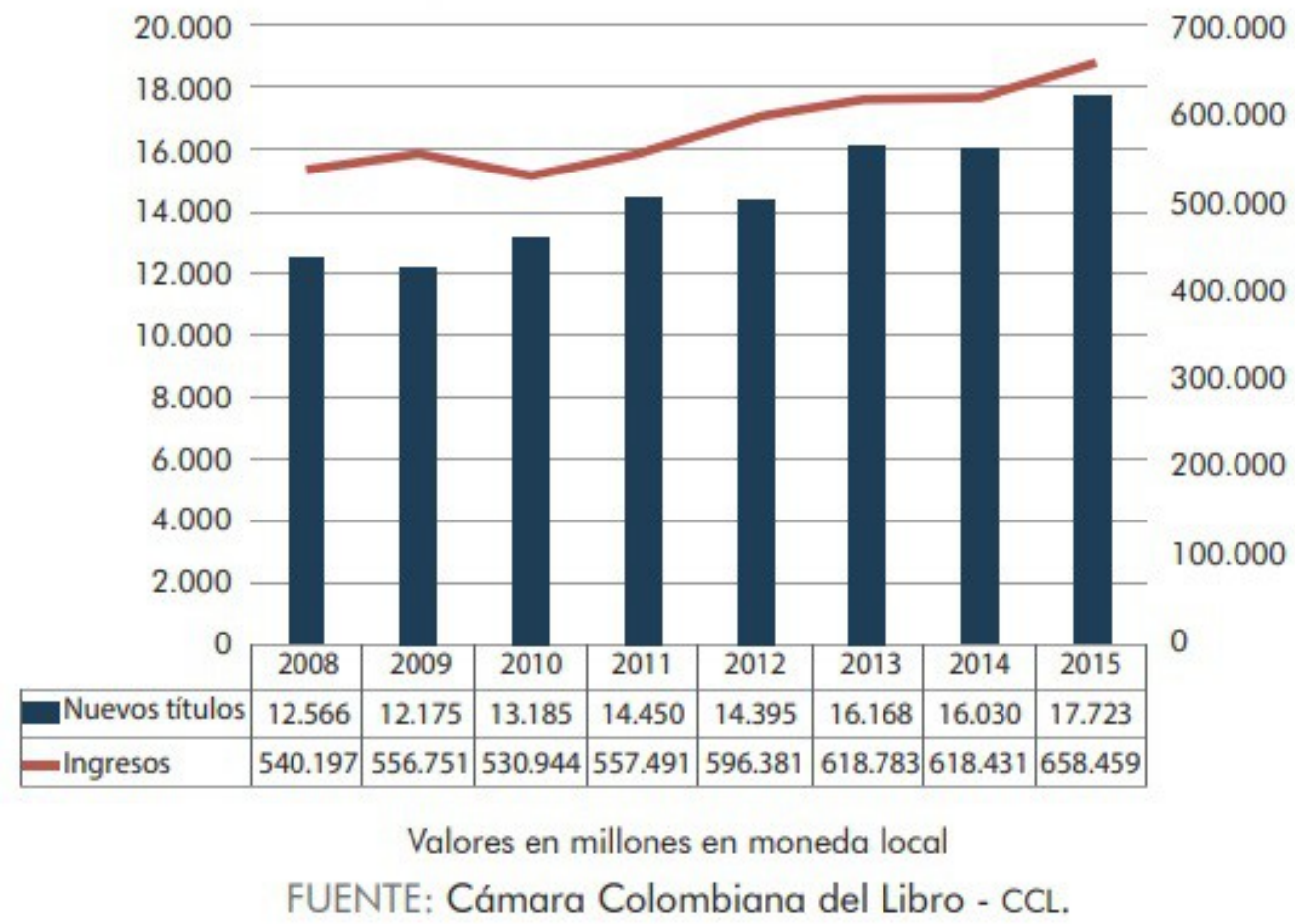

24. Tabla producción de títulos. El espacio iberoamericano del libro 2018 del CERLALC. Imagen tomada de https://cerlalc.org/publicaciones/el-espacio-iberoamericano-del-libro/

Dicho análisis también ofrece un comparativo entre la producción de seis editoriales en Colombia y las ordena por la cantidad de ejemplares producidos, así como por su participación en la producción del conjunto de editoriales comerciales, es decir, permite percibir los rendimientos empresariales y la participación de cada empresa en el mercado.

Como se aprecia, actualmente en el país hay dos grandes casas editoriales internacionales, grupos reconocidos a nivel mundial por su trabajo, por los múltiples sellos con los que cuentan y los autores reconocidos a los que publican, se habla de Penguin Random House, originalmente inglesa y Grupo Planeta, proveniente de España. 
TABLA 14. Las seis editoriales principales en Colombia clasificadas por ejemplares producidos y su participación en la producción del conjunto de editoriales comerciales (2017)

\begin{tabular}{|c|c|c|c|c|}
\hline Editorial & $\begin{array}{l}\text { Total títulos } \\
\text { con ISBN }\end{array}$ & $\begin{array}{c}\text { Total de } \\
\text { ejemplares }\end{array}$ & $\begin{array}{l}\text { Porcentaje } \\
\text { de títulos } \\
\text { con ISBN }\end{array}$ & $\begin{array}{l}\text { Porcentaje } \\
\text { de } \\
\text { ejemplares }\end{array}$ \\
\hline $\begin{array}{l}\text { Editorial Planeta } \\
\text { Colombiana S. A. }\end{array}$ & 919 & 1.903 .509 & $13,14 \%$ & $12 \%$ \\
\hline $\begin{array}{l}\text { Penguin Random } \\
\text { House Grupo Editorial } \\
\text { S. A. S }\end{array}$ & 697 & 1.862 .128 & $9,97 \%$ & $11,74 \%$ \\
\hline $\begin{array}{l}\text { Educativa S. A. S. } \\
\text { (Parte de Santillana) }\end{array}$ & 459 & 898.132 & $6,56 \%$ & $5,66 \%$ \\
\hline Leyer Editores Ltda. & 161 & 683.486 & $2,3 \%$ & $4,31 \%$ \\
\hline $\begin{array}{l}\text { Grupo Editorial lbáñez } \\
\text { S. A. S. }\end{array}$ & 141 & 564.266 & $2,02 \%$ & $3,56 \%$ \\
\hline Ediciones SM S.A. & 211 & 454.027 & $3,02 \%$ & $2,86 \%$ \\
\hline $\begin{array}{l}\text { Participación de las } \\
\text { seis editoriales }\end{array}$ & 2.588 & 6.365 .548 & $37,01 \%$ & $40,14 \%$ \\
\hline $\begin{array}{l}\text { Total editoriales } \\
\text { comerciales }\end{array}$ & 6.994 & 15.857 .211 & & \\
\hline
\end{tabular}

FUENTE: agencias nacionales del ISBN. CÁLCULOS: Cerlalc.

25. Principales editoriales en Colombia 2017. El espacio iberoamericano del libro 2018 del CERLALC. Imagen tomada de https://cerlalc.org/publicaciones/el-espacio-iberoamericano-del-libro/

Así mismo, en este grupo hay participación de editoriales de textos escolares y/o académicos como Educativa (antes Santillana), Leyer Editores, SM y Grupo Editorial Ibáñez.

Estas empresas generan el alrededor del $40 \%$ de toda la producción del mercado editorial colombiano. Esto demuestra no solo la competitividad sino también la fuerza de los grupos editoriales extranjeros que con grandes capitales acaparan una buena porción del mercado. 
El restante es repartido entre otras múltiples editoriales. Algunas de las editoriales nacionales más destacadas por su tamaño, capacidad de producción, línea de trabajo editorial y/o catálogo, podemos mencionar: Panamericana Editorial, Villegas Asociados, Angosta, Babel Libros, Calixta Editores, Laguna Libros, Luna Libros, Rey Naranjo, Jardín Publicaciones (dedicada a libros sobre arte y libro objeto), Ícono Editorial, Sílaba, Editorial Atenea, Alfaomega colombiana, Ecoe Ediciones, Siglo del Hombre Editores, entre otras. Entre las editoriales de ilustración, cómic y novela gráfica encontramos: Editorial Monigote, Editorial Robot, Cohete Cómics, Tragaluz Editores, La Silueta, Destiempo Libros, Cardumen Publicaciones (especializada en libro objeto), Taller Colmillo (dedicada al diseño editorial y al fanzine).

\section{Panorama de editoriales en el país y sus líneas de trabajo}

De acuerdo al análisis desarrollado por Lado B para el Grupo de Emprendimiento Cultural del Ministerio de Cultura, las editoriales en Colombia realizan varias actividades económicas, mezclando la importación, distribución y venta de libros con otras, para conseguir la sostenibilidad y expansión de su actividad económica. Así se establecen líneas de negocio y grupos de empresas que obedecen a varios cruces de actividades, entre los que encontramos:

1. Importadores y distribuidores: Generalmente son empresas que no editan contenidos, ni poseen puntos de venta. Se encargan de vender a agentes intermediarios, como librerías, grandes superficies, o a universidades, bibliotecas y organizaciones gubernamentales.

2. Importadores con punto de venta: Sus principales actividades son la importación y la distribución de sus obras editoriales, a través de su punto de venta. Generalmente son empresas extranjeras.

3. Puntos de venta. Conocidas como librerías o libreros. Se dedican a la venta de libros al público por medio de establecimientos físicos o virtuales.

4. Editoriales con punto de venta: Se dedican a la edición y venta de contenidos en su propio punto de venta. Algunas veces también ofrecen materiales de otras editoriales. Muchas de estas tienen una inclinación a la producción de textos educativos, didácticos, religiosos, entre otros. 
Algunas consideraciones para este grupo durante los años de análisis, entre 2013 y 2015 :

- El número de editoriales que conforman este grupo representaron entre el $14 \%$ y el $16 \%$ del total de empresas del sector.

- El monto total de las ventas declinó en esos tres años: en 2013 fue el $18 \%$ del total de ventas del sector mientras que en 2015 fue el $10 \%$.

- El número de ejemplares vendidos no cambió significativamente para el 2015, pero el precio promedio del libro bajó a casi la mitad.

- En 2013, el canal principal de ventas fue la venta directa a colegios, seguido por las en librerías, los libros digitales y las exportaciones. Mientras que, en 2015, casi se igualaron las ventas directas y a través de librerías, las exportaciones se redujeron y los formatos digitales ganaron relevancia.

- Los libros más comprados son los de interés general con $45 \%$ y los didácticos con un $43 \%$, sin embargo, los superan en valores de ventas los textos universitarios con el $48 \%$ puesto que su PVP es mayor.

- Este grupo cuenta con la mayor producción de libros digitales debido a los intereses del sector educativo.

5. Editoriales: Se dedican a editar contenidos, generalmente no importan y no tienen puntos de venta. Su objetivo, es el desarrollo de escritores o la creación de obras literarias y/o ilustradas, en este grupo se incluyen las editoriales independientes.

Consideraciones para los años de análisis, del 2013 al 2015:

- Cuenta con la mayor cantidad de empresas del sector.

- En el 2013 y el 2014 eran 82 empresas, en el 2015 se redujeron a 71, pasando de ser el $47 \%$ del total a ser el $40 \%$.

- En 2013 lograron un total de ventas de $\$ 185.500$ millones de pesos aproximadamente el $30 \%$ del total de ventas del sector. En 2014 las ventas fueron $\$ 133.440$ millones y en 2015 fueron $\$ 143.770$ millones. es decir, un $22 \%$ del total de ventas del sector.

- Estas empresas se especializan en editar contenidos, no en venderlos. La gran mayoría de los libros se producen en el país.

- En 2013 , el $45 \%$ de las ventas se hicieron a través de canales directos y alcanzaron un total de $\$ 84.000$ millones de pesos. El $28 \%$, se hizo a través de librerías y grandes superficies con $\$ 52.000$ millones.

- La exportación es un canal de comercialización importante para estas empresas. 
Aquí vale la pena comentar sobre las editoriales independientes, consideradas de esta manera -es decir independientes- por no tener capital internacional, ni punto de venta propio y por desarrollar contenidos de autores locales, de géneros abiertos pero que escapan a los textos académicos y/o religiosos.

Consideraciones para el periodo analizado:

- En 2013 eran 41 empresas e hicieron el $13 \%$ de las ventas del grupo.

- El canal de ventas más importante fueron librerías y grandes superficies, estas ventas se acercaron al $40 \%$ del total del subgrupo. El segundo canal de ventas fue la venta directa a colegios. Y el tercer lugar lo tuvieron los libros electrónicos.

- Para las editoriales independientes la participación en ferias incide sobre el total de sus ingresos anuales. Espacios como la Feria Internacional del Libro de Bogotá son de gran importancia en el desarrollo de su actividad comercial.

- En 2013 las editoriales independientes produjeron en total 1,2 millones de ejemplares, un equivalente de $\$ 25.000$ millones de pesos en ventas. En 2014 el total fue de 1,9 millones y en 2015 se acercaron a esa misma cantidad.

- La caída en ventas del sector editorial en 2014 y 2015 afectó menos a las editoriales independientes, debido a su tamaño y operación.

- Al comprar derechos de autores noveles nacionales o extranjeros y llevar a cabo las tareas como identificar, curar, editar, publicar y promover autores, consideran que este trabajo no ha sido comprendido por el sector público y, por tanto, que no reciben los beneficios que deberían.

- Las editoriales pequeñas deben sobre llevar costos fijos altos, principalmente los asociados a la impresión y muchas veces deben optar por diversificar sus negocios para llegar a ser negocios sostenibles.

6. Editores e importadores: Editan e importan contenidos. Son principalmente empresas extranjeras que importan libros de su casa matriz. En muchas ocasiones su producción se relaciona con libros juveniles y de literatura utilizada en instituciones académicas.

Consideraciones para los años analizados:

- En 2013, este grupo vendió el 33 \% del total de ejemplares en el país.

- En 2014, sus ventas ocuparon el $25 \%$ dentro del total de ejemplares del país.

- En 2015 las ventas se ampliaron al $27 \%$ del total.

- La subida del dólar hizo que este grupo pasara de tener el $30 \%$ del monto total de ventas al $38 \%$ en el 2014 y el $34 \%$ en el 2015.

- Librerías y grandes superficies son el canal de ventas más importante del grupo, 
seguida por las ventas directas a colegios, luego están las ventas directas al sector público y a universidades.

7. Editores e importadores con punto de venta: Mezclan la edición, la importación y la venta de sus obras y las de otras editoriales en sus puntos de venta.

- Las empresas que constituyen este grupo fueron 19 el 2013, 20 en el 2014, y 19 en el 2015.

- Este grupo incluye editoriales como la Sociedad de San Pablo, la Sociedad Bíblica Colombiana y la empresa Verbo Divino, que crean, importan, distribuyen y venden contenido religioso. También incluye otras empresas como Pearson Colombia, Plaza y Janes, y Fondo de Cultura Económica que venden libros de interés general, didácticos y universitarios que constituyen sus principales ventas.

- El grupo representa alrededor del $11 \%$ del total de empresas editoriales del país, pero ha percibido ingresos de alrededor del $18 \%$ en 2013 y el $26 \%$ en 2015.

- El canal de ventas más importante fueron librerías, grandes superficies y puntos de venta propios con el $46 \%$. Cabe señalar que los márgenes de utilidad son superiores cuando la misma casa editorial tiene un punto de venta propio puesto que no debe cubrir de costos de intermediación. Luego le sigue las ventas directas a universidades con un $19 \%$ del total de ventas del grupo.

Este panorama permite establecer algunas conclusiones generales:

- Muchas de las empresas que hacen parte del mercado editorial colombiano a pesar de las variaciones o dificultades que se presentan se mantienen trabajando, es decir, hay estabilidad.

- Es importante para empresas editoriales nacientes contar con una capital semilla o de riesgo que pueda recuperarse en un largo plazo.

- Tener un punto de venta propio puede ser un componente importante en la estrategia de ventas.

- Generar alianzas con empresas que proporcionen el servicio de impresión para acordar plazos o facilidades de pago puede considerarse una estrategia importante para empresas nacientes.

- El mercado se mantiene en constante desarrollo e incluso crecimiento a pesar de las fluctuaciones.

- Empresas internacionales con trayectoria y capitales de inversión grande cuentan con una mayor participación en el mercado. 


\subsection{Aspectos jurídicos}

Casa Reflector S.A.S. es una empresa colombiana, que crea contenidos gráficos, audiovisuales, escénicos, formula proyectos híbridos en estas áreas y desarrolla estrategias educativas con y para el arte.

Esta empresa se conformó en 2011 con la finalidad de llevar a cabo actividades artísticas principalmente teatrales, en 2015 se realizó una reestructuración donde cambiaron los socios y la empresa empezó a desarrollar proyectos con varios lenguajes artísticos.

Para iniciar el trabajo, la empresa presenta proyectos a diversas convocatorias para recibir financiación y poder adquirir experiencia. Luego de un tiempo de actividad y de estudiar el mercado de convocatorias encontramos que tanto el área social, como el campo escénico, obligan a la presentación de propuestas desde empresas sin ánimo de lucro, por tanto, se decidió crear la Fundación Casa Reflector (con razones sociales casi iguales puesto que podríamos manejar un único sitio web, un solo logo e imagen para las dos empresas permitiendo integrar experiencias ya que se trata del mismo grupo de trabajo).

Así desde 2016, la Fundación se interesa por realizar actividades formativas, cursos y talleres alrededor de las áreas mencionadas, así como actividades escénicas. (En el anexo Historia y fotografías Casa Reflector, se muestra en detalle la historia de las empresas y los proyectos desarrollados).

Ambas empresas cuentan con toda su documentación, registro en cámara de comercio y libros contables al día. Al inicio de este año, se actualizaron las actividades económicas haciendo claridad en la especificidad de cada una de las empresas.

Hasta la fecha, Casa Reflector no cuenta con registro de marca, sin embargo, dado el caso que logremos llevar a buen fin alguno de estos dos proyectos, se adelantará este trámite.

A finales de 2019, se inició el desarrollo de dos líneas de negocios: una de estas abarca el desarrollo de experiencias educativas digitales, donde mediante la hibridación de lenguajes: narración, ilustración y humor se comenta la situación del oso de anteojos en Colombia. La otra línea, comprende llevar a cabo recorridos teatralizados en el centro de la ciudad, como una oferta diferente para turistas y locales que buscan conocer la ciudad y aprender un poco más de su historia. 
Así buscamos ampliar la oferta de experiencias educativas y turísticas, y generar un flujo constante de proyectos y caja para la empresa.

En cuanto a la novela gráfica La mano del oso hemos contado con la participación de:

- Un ilustrador y escritor principal.

- Un asistente gráfico, que aplicó color pero que también ha creado algunos materiales como stickers para WhatsApp y gifs para redes sociales.

- Dos coloristas.

- Una investigadora, productora y escritora.

- Una videografo que elaboró el booktrailer y un video promocional.

- Dos personas que apoyan en el componente técnico y conceptual sobre medioambiente y oso de anteojos.

Todas las personas relacionadas aparecen con sus respectivas labores en la página de créditos del adelanto de la primera parte de la obra para dar honra al derecho moral de autor, de momento dicha página se encuentra así: 


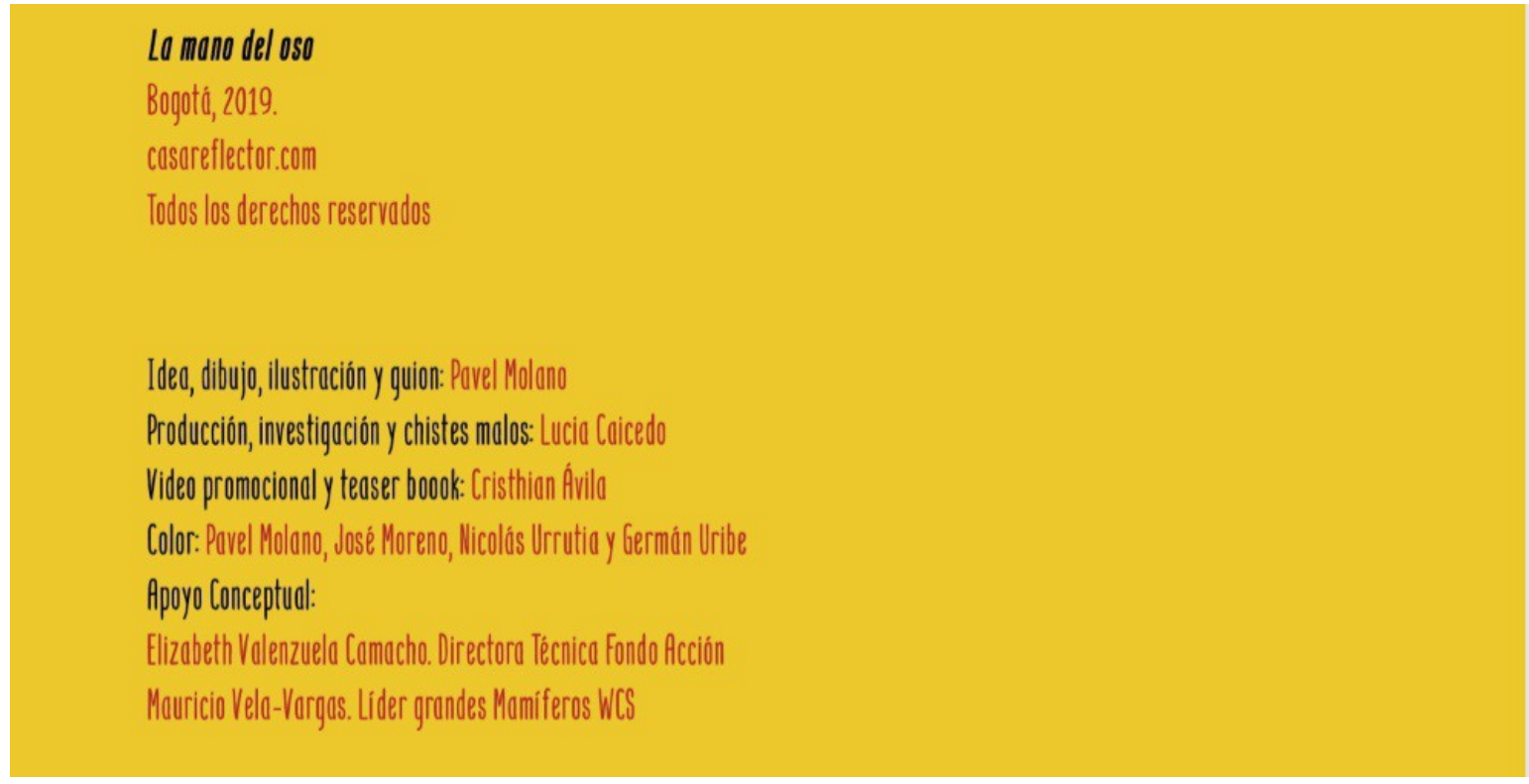

26. Imagen de la página de créditos de La mano del oso. Tomada del machote digital.

Sin embargo, para la versión definitiva y de acuerdo a lo señalado en el artículo 125 de la ley 23 de 1982 se incluirán los siguientes ítems:

a) El título de la obra

b) El nombre de los autores

c) La mención de reserva del derecho de autor y de año de la publicación, precedida del símbolo (C).

d) El nombre y dirección del editor.

e) El nombre y dirección del impresor.

Una de las personas que nos apoya en la parte conceptual, lo hace desde una ONG que se llama Fondo Acción con ellos tenemos planes de elaborar un convenio para trabajar en colaboración, uno de los puntos a establecer son los derechos de autor (morales y patrimoniales).

El registro de la historia y los dibujos de la primera parte se realizaron a nombre del ilustrador y autor de los textos, pero puesto que mi participación ha sido mayor en la escritura de la novela gráfica se registrará como obra en colaboración. 
En el caso que Casa Reflector o los autores de la obra, firmen un contrato con una editorial debe tenerse en consideración no solo los créditos y los aspectos a incluir en la página de legales sino también los aspectos del contrato, el CERLALC da un lineamiento en su sitio web que establece como imprescindible establecer el número de ediciones, de ejemplares, la remuneración de los autores, el plazo de inicio y termino de cada edición, las limitantes al uso de la obra y los derechos de autor.

Dado el caso que el contrato no establezca estos montos de forma expresa, la ley define que deberá ser una sola edición de tres mil ejemplares, que la remuneración del autor se debe establecer en un porcentaje del $20 \%$ sobre los libros vendidos (no sobre los ejemplares del tiraje), el plazo máximo de inicio de la edición son dos meses después de la entrega de los originales y su finalización dos meses después de que se notifique que el libro está agotado en librerías, la obra solo tendrá un uso, deberán salvaguardarse los derechos morales, así como los derechos de modificación e integridad que siempre estarán en manos del autor de la obra por lo tanto, todo cambio, recorte, uso de siglas, deberá ser notificado y aprobado por el(los) autor(es). Los derechos patrimoniales deben ser previamente establecidos y limitados. 


\section{Proyecto La mano del oso}

\subsection{Resumen ejecutivo}

\section{La mano del oso}

Novela gráfica sobre la situación del oso de anteojos en Colombia.

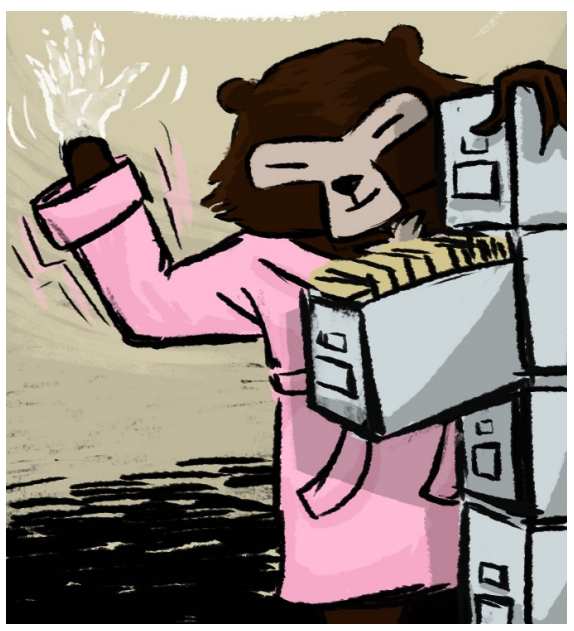

Logline: Elmo, oso andino que ya perdió una garra, hace todo lo posible para no perder también su casa.

Formato sugerido: $17 \times 24 \mathrm{cms}$., tapa blanda, color, encolado, finalizado rústico.

Volumen: Un solo volumen de 70 páginas de contenido aproximadamente + legales. Público objetivo: Dirigido a adultos jóvenes (entre 18 y 35 años).

\section{Descripción del proyecto}

La mano del oso es un proyecto de ficción gráfica que busca de una manera divertida contar sobre la situación del oso andino en Colombia. El detonante de la historia es un tuit de la senadora Paloma Valencia (cuyo perfil en tuiter es @PalomaValenciaL) del 3 de julio de 2016 , donde se pronunciaba al respecto de un ataque de un oso de anteojos a unas reses propiedad de ganaderos del municipio de Torotó, Cauca. En la red social, Valencia, con una desastrosa redacción y fotos explícitas de reses mutiladas, daba a entender que el oso debería pagar los daños causados y evitar, así, su propia muerte.

El mensaje en su primera lectura parece algo risible al pedir que el oso pague por sus supuestos crímenes pero además tiene un velo pendenciero, y de amenaza, al sentenciar que así evitaría su muerte. Horas después, la senadora dijo que fue mal interpretada y que quien debería pagar, y velar por la seguridad del oso es la entidad Parques Nacionales Naturales a quién dirigía su trino; sin embargo, meses después una garra desmembrada de un oso de anteojos llega a las oficinas de Parques Nacionales con una nota donde se advertía que los iban a seguir matando. 
Conociendo el contexto y situación de los osos, se ha identificado algunos conflictos para abordarlos en el transcurso de la historia: la deforestación, el crecimiento desproporcionado de zonas de pastoreo o pastaje, y otras situaciones derivadas del trabajo o uso humano que afectan el hábitat del oso. Estas situaciones muchas veces propician ataques del oso al ganado, despertando malestar entre la población y en ocasiones caza por retaliación.

A este panorama se le suma, el desconocimiento de la especie, la falta de impulso a la ciencia, así como la prelación por prácticas económicas cuestionables y poco sostenibles, por tanto, también consideramos importante señalar las relaciones entre medioambiente y gobernanza.

Buscamos hablarle, por medio del humor, a jóvenes adultos que preocupados por las situaciones actuales que se viven en el país puedan entender y tomar decisiones que favorezcan el medioambiente desde sus prácticas cotidianas hasta en sus opiniones o manera de pensar.

LA MANO DEL OSO

Es un proyecto de novela gráfica que busca despertar reconsideraciones por el medioambiente, principalmente por la situación que el oso de anteojos vive en Colombia.

El público objetivo son jóvenes y adultos jóvenes entre los 18 y los 35 años.

El proyecto busca ampliar su impacto creando un universo online compuesto por publicaciones en un medio de comunicación y en redes sociales. Así mismo, se socializará la inciativa con instituciones que mediante su que hacer resplanden el proyecto, con ellos se implementará la red de amigos de Elmo. Si estos planes tienen éxito, se crearán objetos promocionales para la venta.

\section{MIND MAP}
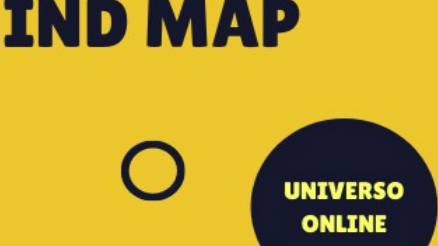

NOVELA

GRÁFICA

O
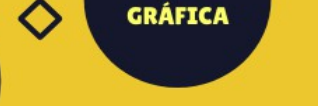

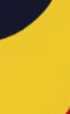
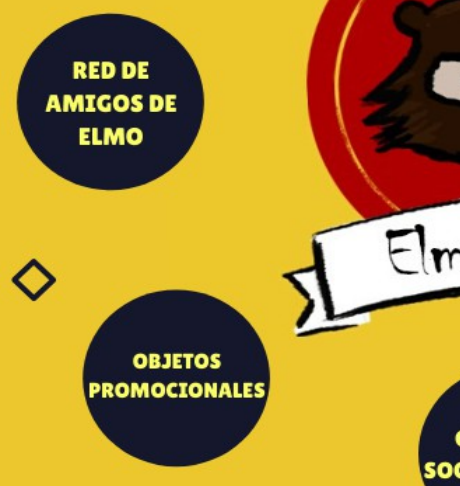

Sánchez

O

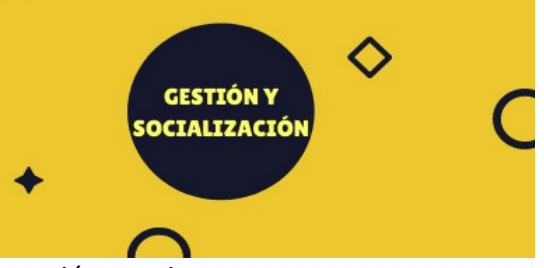

27. Mind Map La mano del oso. Fuente: Elaboración propia. 


\section{Estado actual del proyecto}

La mano del oso fue seleccionada -de entre más de cien iniciativas de toda Colombia- por la Fundación para la Libertad de Prensa -FLIP- dentro del marco del proyecto Revivamos el humor para recibir asesorías en investigación y construcción de guion, así como financiación para el piloto, que consistió en la creación y publicación web de la primera parte de la novela gráfica que se puede encontrar en el sitio: www.casareflector.com.

Para la escritura de las historias contamos con el acompañamiento técnico y conceptual de Fondo Acción y WCS. Se cuenta con un convenio de cooperación con la Fundación Uraku para hacer difusión de actividades, compra de libros y material promocional. Se está en conversaciones con El Santuario del Oso de Anteojos y se está presentado el proyecto a varias Fundaciones que trabajan en pro del oso y de la mejora de situaciones de medioambiente en general.

Así mismo, se ha propuesto al diario El Espectador, al sitio web Los Danieles, columnas sin techo; al periódico El Tiempo e indagamos en Semana Sostenible, la posibilidad de abrir un espacio para una columna con periodicidad a definir, donde se aborden temas ambientales de una forma más amplia a los tratados en el libro. Es decir, se busca ampliar el universo de la novela gráfica a un entorno digital desarrollando más al personaje y llegando a un público más amplio. De estas gestiones aún no hemos recibido respuesta.

También continuamos adelantando gestión con el Grupo Planeta, desde Planeta Cómics no están interesados por el tono didáctico de la propuesta, sin embargo, han remitido la propuesta al área de proyectos especiales puesto que encuentran potencial en ella, estamos iniciando el proceso de gestión.

En cuanto al desarrollo de la propuesta, actualmente se cuenta con el guion completo de la novela gráfica, (lo encuentran entre los anexos), con alrededor de 33 páginas ilustradas (también en la carpeta de anexos) y se continúa trabajando en las artes finales de la misma. 


\subsection{Diagnóstico y problemática}

Las experiencias que combinan las posibilidades de las artes gráficas y la narración son en la actualidad un formato atractivo, abierto tanto a la exploración temática y formal, como a robustecer experiencias en otros ámbitos como lo es el pedagógico y el periodístico. En este sentido, el desarrollo de productos que contribuyen tanto a la instrucción o capacitación, a la divulgación y que -de ser posible- favorezcan la sensibilidad hacia un tema en específico, hacen parte del creciente inventario de herramientas educativas y de opinión.

Teniendo en consideración el público objetivo y como resultado de una búsqueda de material alrededor del tema específico a tratar, el oso de anteojos y su condición en Colombia, se encontraron dos tipos de piezas, las que van dirigidas a un público infantil y las que son destinadas a los adultos.

Generalmente a los pequeños se destinan recursos como cuentos, libros para colorear, cartillas con inclusión de fotografías e ilustración, revistas y en menor medida cómics. A continuación, se incluye un breve listado de algunos de los materiales bibliográficos encontrados:

- Serie de cómics titulados Herederos del planeta creados por Parques Nacionales Naturales en 2016. Así mismo, esta entidad ha creado algunos otros materiales didácticos para público infantil proporcionando información y propiciando la sensibilización entorno a $\quad$ a $\quad$ estos temas. http://www.parquesnacionales.gov.co/portal/es/interesting/los-ninos-en-losparques-nacionales/

- Cartilla infantil con datos y partes para colorear desarrollada por Corporinoquia y Orinoquía diversa. https://issuu.com/e latova/docs/sin t tulo-3 6ecde9e7653daf

- Cartilla infantil sobre el oso de anteojos desarrollada por la CAR. https://www.car.gov.co/uploads/files/5b745e2ca177e.pdf

- Cartilla infantil Conozcamos al oso Jucumari creada por WWF Bolivia. http://awsassets.panda.org/downloads/10 el_oso jucumari oso de anteojos. $\underline{\mathrm{pdf}}$ 
- Cartilla infantil El oso andino en Mamapacha y Bijagual creada por dos entidades en el departamento de Boyacá.

http://fauna.corpochivor.gov.co/oso-de-anteojos/\#oso-de-anteojos/page1

- El libro infantil ECO S.O.S que habla sobre el medioambiente y propone tareas para desarrollar con los niños, el protagonista es un oso.

https://villegaseditores.com/eco-s-o-s

- $\quad$ "Las Aventuras de la Superiguana" es una cartilla que a modo de historieta cuenta los infortunios que vive Ana al ser víctima del tráfico de especies. Ésta es una herramienta de cultura ciudadana generada por CorpoCesar para reducir el tráfico ilegal de fauna silvestre. Sí bien no habla del Oso de Anteojos es una pieza que guarda similitud a las consideradas por este trabajo. https://www.corpocesar.gov.co/Corpocesar lanzo campana .html

- Libro para colorear "Mamíferos de Bogotá y dónde encontrarlos" es un libro elaborado por Sara Gabriela Acosta Morales y Rodrigo Mutis Rangel, biólogos de la Universidad Nacional de Colombia, que con busca dar a conocer la fauna que habita en la ciudad de Bogotá. https://t.co/MXkysOOuTn?amp=1

- Libro ilustrado "El Espíritu del Páramo" de Celso Román. Editoral Monigote. Narra las aventuras del explorador escocés Edward Mackenzie que se adentro en Colombia, buscando el tesoro de la leyenda de "El Dorado". La distribuidora lo cataloga para público joven, sin embargo, el CERLALC lo incluye en un catalogo de libros infantiles para el desarrollo sostenible.

https://www.libreriacasatomada.com/libro/el-espiritu-del-paramo 40252

También se encontraron algunas experiencias que promueven la escritura de relatos cortos o cuentos en diferentes regiones de Colombia con niños(as) campesinos que comentan sobre el habitat y/o presencia del oso andino y otros animales de fauna silvestre.

- Libro ilustrado "Cuentos del oso andino del Perijá" iniciativa desarrollada por Fundación Wii y Endémica Studios, que agrupa ocho relatos de niños de la región del Cesar https://issuu.com/endemicastudios/docs/tales bears abril 1

- Libros de cuentos virtuales desarrollado por Rainforest Alliance con niños en diferentes regiones de Colombia, la narración corta "El hogar andino de Chayo" hace referencia al oso https://www.rainforest-alliance.org/lang/es/kids/Stories\# 
Entre los recursos dirigidos a adultos, y que mantenen la hibridación de componentes gráficos y narrativos, podemos mencionar cartillas, algunos artículos, sea académicos o informativos, que desde una perspectiva científica, política o económica abordan temas puntuales relacionados con medioambiente. A continuación relacionamos algunos de los encontrados:

- El Ministerio de Medioambiente creó el Programa Nacional para la conservación en Colombia del oso andino, este documento en forma de cartilla incluye un diagnóstico de la especie, principales presiones a la que está sometida, grado de amenaza de acuerdo a los criterios de la UICN, estado actual de la población y del habitad; y traza los objetivos, metas y rutas de trabajo para encaminar la conservación de la especie.

http://www.minambiente.gov.co/images/BosquesBiodiversidadyServiciosEcosiste micos/pdf/Programas-para-la-gestion-de-fauna-y-flora/472_cartilla_osos2.pdf

- El parque Jaime Duque en alianza con la Gobernación de Cundinamarca han creado un material de educación ambiental como parte de las estrategias desarrolladas para que la especie sea conocida y protegida por su importancia en el ecosistema y su labor como protector de páramos y bosques en la región de Cundinamarca. https://issuu.com/parquejaimeduque/docs/elosoandino

- La WCS en asocio con algunas organizaciones locales de Cusco, trazaron la Estrategia para la conservación del oso andino en el santuario histórico de Machupicchu y el área de conservación regional Choquequirao.

https://peru.wcs.org/es-es/especies/oso-andino.aspx

- El Servicio Nacional Forestal y de Fauna Silvestre SERFOR publicó el Plan Nacional de Conservación del Oso Andino (Tremarctos ornatus) en el Perú, documento que traza planes de trabajo claros con objetivos, metas e indicadores.

https://www.serfor.gob.pe/wpcontent/uploads/2018/10/Plan Oso FINAL BAJA.pdf

La problemática relacionada con la comunicación de contenidos académicos, o que cuentan con un grado de especificidad temática, radica en la manera de exponer la información destinada al público objetivo para que este proceso se constituya un factor de cambio o sensibilización. 
Así mismo, a partir de los resultados obtenidos en la búsqueda de materiales relacionados con el tema en mención, se identifica la carencia de recursos destinados a público joven, ubicados entre los 15 y los 25 años.

A partir del estudio de tendencias actuales como la redificación, que revalora el entretenimiento como medio para obtener resultados exitosos en procesos educativos y en metodologías propias de la educación como el blending learning que estimula el aprendizaje autónomo con una mezcla de procesos presenciales y por internet, favoreciendo el uso de otro tipo de recursos, que lleven al aula la posibilidad de contar con procesos personalizados. Se considera que la hibridación de textos y gráficos puede proporcionar al lector una sensación placentera que facilita la comprensión e introspección de conceptos generando el enganche temático que se requiere.

Teniendo en cuenta lo anterior, es intención de esta propuesta la articulación de las características previamente anotadas (hibridación entre narración y gráficos), la generación de un material que sea atractivo para una audiencia amplia (jóvenes y jóvenes adultos), que desde la risa y el desenfado conecte a esos receptores con el tema del medioambiente en Colombia, especialmente con la situación de vulnerabilidad del oso andino y su hábitat.

\subsection{Profundización temática y referentes}

Se realiza a continuación una breve profundización en algunos los aspectos relevantes a la realización del proyecto La mano del oso.

\section{Los libros: la escritura y la lectura}

El libro es muchas cosas. Un receptáculo de la memoria, un medio para superar las limitantes del tiempo y el espacio, un lugar para la reflexión y la creatividad, un archivo de nuestra experiencia y la de los otros, una fuente de iluminación, de felicidad y, en ocasiones, de consuelo, una crónica de eventos pasados, presentes y futuros, un espejo, un compañero, un maestro, una convocatoria de los muertos, un divertimento; el libro en sus muchas encarnaciones, de la tableta de arcilla a la página electrónica, ha servido por mucho tiempo como una metáfora de muchos de nuestros conceptos y empresas esenciales. (Manguel, 2015, p. 18) 
A lo largo de la historia los libros se han consagrado como herramienta y extensión del pensamiento, han sido la forma de asegurar la circulación del conocimiento y el espacio oportuno para preservar la memoria.

Resulta interesante y motiva a la elección del formato propiciar la lectura, que como ejercicio exige de la presencia activa del lector para completar el trabajo del escritor. Así, se entiende el libro como punto de convergencia entre el lector y el escritor, como la suma de particularidades, intenciones, velocidades de la que se desprenden ideas, propiciar que la lectura sea una experiencia, que despierte emociones principalmente la risa o donde se invite a la relectura y en cada uno de estas, se encuentren nuevos elementos.

La escritura entendida como un juego al disponer palabras, y en este caso también de dibujos, colores, texturas para generar sentidos y sensaciones alrededor de un tema que parece alejado de lo social pero que realmente está en el centro de la vida misma y del territorio. Este ejercicio nos recuerda las palabras de Deleuze y Guattarri:

Igual ocurre con el libro y el mundo: el libro no es una imagen del mundo, según una creencia muy arraigada. Hace rizoma con el mundo, hay una evolución aparalela del libro y del mundo, el libro asegura la desterritorialización del mundo, pero el mundo efectúa una reterritorialización del libro, que a su vez se desterritorializa en sí mismo en el mundo, (si puede y es capaz). (Deleuze y Guattarri, 2002, p. 16)

En su libro Mil Mesetas, los autores reflexionan sobre el papel, función, imagen, significado del libro, si bien, aventurar a concluir que el libro que se desprende de este ejercicio desterritorializará el mundo son palabras mayores, sí busca generar cambios en el lector proporcionándole la posibilidad de conocer otras perspectivas de situaciones actuales desde el desenfado y la tranquilidad.

La creación, en este caso: ejercicio de investigación, escritura, ilustración y color proporcionó una aventura que -a manera de rizoma- despejó canales de tránsito de ideas, impulsó nuevos métodos de trabajo, invitó al ajuste, a la adaptación, a búsquedas que no estaban trazadas en los planos originales y que hoy hacen de esta propuesta lo que es.

\section{Los cómics y sus poderes}

Los antecedentes del cómic se remontan a siglos atrás, por ejemplo, en el antiguo Egipto se usaron papiros con sucesiones gráficas para mostrar los momentos de la vida de los 
faraones. En el Imperio Romano una columna fue tallada en bajorrelieve con una serie gráfica secuencial para contar las aventuras de Trajano frente a los Dacios, y por supuesto, dar cuenta de sus victorias. En Francia se bordaron piezas gráficas en formato horizontal, formando un tapiz de casi 70 metros de largo, por 50 centímetros de alto, para narrar las aventuras de la guerra normanda, esta pieza es conocida como el Tapiz de Bayeux o Tapiz de la Reina Matilde.

Con el desarrollo de la imprenta y el surgimiento de los periódicos se fortalecen expresiones como las historietas breves y la caricatura, que toman una dimensión política equivalente al comentario breve, al gag que irrumpe con levedad en un escenario de suma seriedad.

Posteriormente las historias folletinescas, así como el nacimiento de revistas y/o suplementos infantiles incluyeron temas ficcionales y separaron los ámbitos temáticos de la caricatura y el cómic.

El paso del tiempo propició el desarrollo de un lenguaje para las comiquitas, favoreciendo la instalación de metáforas visuales, que hoy por hoy, hacen parte del imaginario colectivo como las estrellitas que orbitan alrededor de la cabeza después de un golpe o el corazón roto después de una noticia triste. La ordenación, diseño uso de viñetas, también son recursos, que se aprenden y comprenden como diría Román Gubern "a fuerza de leer cómic".

El fortalecimiento del cine también ha impulsado el formato del tebeo, la actual relación de personajes y universos que pasan de un lenguaje al otro hacen que se retroalimenten favoreciendo a ambas industrias.

La consolidación del formato de cómic -así como la novela gráfica- y las múltiples experiencias alrededor de éste, impulsan el uso de historietas en contextos cada vez más amplios.

Sin embargo, y a pesar de que la lectura de monitos -al igual que los libros convencionalesimplique un compromiso por parte del lector, puesto que se debe completar el mensaje híbrido (imagen y texto), la percepción común dicta que la lectura de los dibujos es más fácil, divertida e incluso rápida que la tradicional. Esta percepción se convierte en un elemento que juega a favor, al momento de abordar temas olvidados, complejos o difíciles y es por esto, entre otras cosas, que su uso pedagógico cada vez es más frecuente. 


\section{Cómics y pedagogía}

Como se comentó el paso del tiempo, el fortalecimiento del lenguaje y la industria del cómic, permitieron que las historietas permearan otros espacios como la escuela. En la actualidad es común -en procesos de educación no formal o complementaria- encontrar contenidos relacionados a las historietas, que hacen parte de estrategias de fortalecimiento a la lectura.

Sin embargo, el libro With Great Power Comes Great Pedagogy: Teaching, Learning, and Comic Books, va un poco más allá, los autores observan la importancia de los cómics como herramienta pedagógica incluso en espacios de educación formal y reseñan cuatro tipos de pedagogías relacionadas con cómics destinadas a la sala de aula:

- La enseñanza con cómics.

- La enseñanza de comics.

- La enseñanza mediante la producción de cómics.

- La enseñanza mediante la producción haciendo énfasis en el fortalecimiento de procesos de pensamiento.

Así, la enseñanza con cómics es usada para -por medio de las historietas- hablar de otros temas.

La enseñanza de cómics, los emplea como piezas narrativas propiciando el desarrollo de la lectura, la lengua, el aprendizaje de otros idiomas, así como la profundización de sus elementos facilitando el estudio de aspectos como la estructura narrativa, los elementos del relato $u$ otros puntuales que pueden hacer parte de planes de estudio de asignaturas artísticas o relacionadas.

La enseñanza a través de la producción de cómics, que introduce la parte formal de este medio, es decir el trabajo sobre la hibridación entre textos, diálogos e ilustración; ofreciendo una alternativa a los estudiantes frente a las estructuras textuales que normalmente estudian en el aula.

Y, por último, la enseñanza de la producción de cómics que -como es de suponer- va dirigida a la creación de una tira cómica, sin embargo, en esta oportunidad tendría un énfasis en las actividades que resultan ser herramientas interesantes para el fortalecimiento y entendimiento de los procesos de pensamiento, y que, por lo tanto, ayudan a desarrollar capacidades de aprendizaje y la comprensión de lectura. 
Aportando a este último tipo de enseñanza, varios de los autores consultados por los tres investigadores vinculados al libro, mostraron la importancia del garabato como una visualización de los procesos de pensamiento y consideraron que las marcas o grafos espontáneos suelen ayudar a pensar, incluso afirman que el dibujo puede ser una traducción de lo que se experimenta, facilitando la comprensión de lectura, así como el entendimiento de situaciones y espacialidades.

Adicionalmente, el cómic -como se comentó en otro aparte del presente documentotiende a ser una herramienta importante dentro de estrategias pedagógicas como el blending learning y la ludificación puesto que su lectura puede dar herramientas conceptuales que facilitan el trabajo colectivo parcialmente guiado por el docente.

\section{El cómic como vehículo de narración de no ficción}

Desde sus inicios el cómic se ha mostrado como una alternativa para hablar de temas sociales, incluso, para abordar situaciones difíciles como la muerte, la guerra, el desplazamiento; en este sentido Joe Sacco, el autor de novelas gráficas periodística, dice en una entrevista:

El cómic tiene una fuerza que no tiene ninguna otra forma de reportaje. Sus imágenes repetidas enfocan la realidad de manera más lenta, a veces silenciosa, a veces con bocadillos, y trabajan en la mente del lector, que puede escoger su ritmo. (Quintero J. y Sacco, J., 2017)

Y en otra entrevista amplía:

To me, it's somewhat simple. I think people are compelled by images. Something like the Bosnian war, when I came back from my experiences there, and I was speaking to people, they were interested, but in about two or three minutes their eyes are glazing over. It's just a lot of information you 're presenting to them, you're trying to be careful, you realise they don't really understand it, and they're glad you're safe and they're: "Ok, wow, sounds amazing, but now let's go to the movie", or something. And I understand it, it just seems really over whelming, people are over whelmed by what goes on in the world, I think. So how do you make that how do you tell people about something that they could probably digest if they took a breath and had a look. So, the thing about comics, it has this very visceral impact. You open up the book, and if the drawings have a truth to them the reader is immediately in that picture. They see the architecture, they see the clothing, they 
see all that stuff, the background, and it sort of situates them immediately. And that's just by function of opening up the book. To me it's sort of a popular front of genres or ways of approaching a subject, this is just my way of approaching it. The one thing I think you can do with comics that's difficult to do elsewhere is take people back into the past. And the drawing hand allows those transitions to be made easily. (Dahlman, C. Holland, E. \& Sacco, J., 2016, P. 209 - 210) ${ }^{1}$

El poder narrativo del cómic, permite captar los acontecimientos más rápidamente, la información visual se complementa con el texto permitiendo una construcción más completa, así los lectores llevan a cabo una lectura más contemplativa y placentera.

La obra de Sacco, entre la que se incluyen novelas gráficas como Palestina e Historias de Bosnia es prueba de ello. En la década de los años 90 , Sacco escandalizado por la visión de los periodistas norteamericanos y su forma de cubrir la ocupación en Palestina comienza a estudiar sobre la situación. Pocos años atrás había abandonado la idea de dedicarse al periodismo escrito y se había comenzado a forjar una carrera en la industria del cómic.

Un día, buscando cruzar sus dos intereses, decidió que viajaría a los Territorios Ocupados y que así podría hacer un cómic sobre sus experiencias, como una suerte de memorias de viaje ilustrado. Sin planearlo mucho, Joe viaja por Israel y Palestina durante dos meses y medio, lleva un diario detallado donde registra todo el suceso que vive, adicionalmente realiza numerosas entrevistas (dicen que más de 70) y lo escribe todo en sus cuadernos, como parte de su trabajo de campo. En dichos cuadernos también dibuja.

\footnotetext{
1 Para mí es algo sencillo. Yo pienso que las personas se ven influenciadas por las imágenes. Algo como la guerra en Bosnia, cuando volví de mis experiencias allá, y hablaba con la gente, estaban interesados, pero en unos dos o tres minutos sus ojos se velaban. Es mucha información la que les estás presentando, tú estás tratando de tener cuidado, pero te das cuenta que ellos realmente no lo entienden, y están contentos de que estás bien y te dicen: "Ok, wow, suena increíble, pero ahora vamos al cine", o algo así. Y yo lo entiendo, parece realmente abrumador, la gente está abrumada con lo que pasa en el mundo, pienso yo. Así que cómo haces eso, cómo le cuentas a la gente acerca de algo que ellos podrían digerir si pudieran tomar un respiro y pudieran echar un vistazo. Entonces, lo de los cómics, es que tiene un impacto visceral. Tú abres el libro, y si los dibujos son sinceros, el lector va estar inmediatamente inmerso en la imagen. Ellos ven la arquitectura, ven la ropa, ellos lo ven todo, el fondo, y los sitúa inmediatamente. Y eso es sólo con la función de abrir el libro. Para mí, es un tipo de frente popular, de género o fomas de acercarse a un tema, está es mi manera de abordarlo. La única cosa que yo creo que puedes hacer con cómics, que es muy difícil de hacer en otro medio, es llevar a la gente al pasado. Y la mano dibujante permite que esas transiciones sean hechas fácilmente. (Dahlman, C. Holland, E. \& Sacco, J., 2016, P. 209 - 210) Traducción Valentina del Pino.
} 
Luego del viaje se muda a los Estados Unidos donde -para sorpresa suya- una editorial recibe su propuesta de cómic documental y la convierte en una serie, con tomos de 24 a 32 páginas que son lanzados aperiódicamente entre 1993 y 1995.

Su estilo de dibujo es bastante detallado, las amplias panorámicas están llenas de juegos de sombras, texturas y registra hasta los más mínimos detalles proporcionando realismo a la escena. La paleta de color se centra exclusivamente en el blanco y negro lo que le da un tono sobrio, aunque, el manejo redundante e incluso barroco de las líneas y puntos que forman texturas en la imagen suplen de alguna manera el manejo de color. Los personajes, que pueden resultar para muchos caricaturescos, conservan un sentido antropomórfico superlativo y generalmente están en poses o ángulos bastante dramáticos para la acción. Y por supuesto, el autorretrato que hace evidente y clara la perspectiva del autor, que está presente durante todo el tiempo en la historia.

De otro lado, encontramos como referente conceptual, las propuestas de Positive/Negative. Su director, Ben Dix, tuvo una fuerte experiencia de vida en el Congo, donde trabajó por varios años con Naciones Unidas para respaldar a las comunidades en guerra; sobrevuelos, explosiones, masacres, Ben salvó su vida y la de algunos de sus amigos, pero los recuerdos y la culpa de dejar el Congo lo acompañaron por muchos años hasta que decidió contar todo en un cómic. Y lo que parecía un ejercicio de catarsis se convirtió en documento y memoria de varias comunidades que se vieron seriamente mermadas por la guerra.

A partir de esto, Ben decide que su trabajo como antropólogo se centrará en dar voz a personas o sociedades que viven situaciones complejas o incluso aterradoras mediante el desarrollo de cómics, ilustración y/o fotografía. A diferencia de Sacco, Ben se apoya en artistas para contar las historias que él escucha en los viajes que realiza a diferentes lugares, donde conoce a personas, a quienes les cuenta de su vida, su participación en la guerra o cómo un cómic lo salvó. Para Ben, el estilo de cada cómic, depende de cada artista, quien es libre de desarrollar sus ideas, así la parte formal de cada pieza es completamente diferente.

En Colombia, el cómic y el periodismo gráfico son incipientes, ya lo diría el dibujante conocido como Truchafrita en el Decálogo para el dibujante de historietas en Colombia: "No hay historietas en Colombia, pero seguiremos dibujándolas". 
El decálogo del dibujante de historietas, en Colombia

1. Soy dibujante de historietas, no soy caricaturista ni tampoco ilustrador.

2. No hay historietas en Colombia, pero como nos gusta hacer eso seguiremos dibujando.

3. Viviremos del aire... A los ilustradores les pagan una miseria, a los caricaturistas con el "hágase conocer" y a los historietistas...

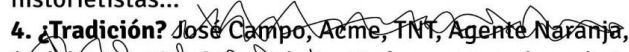

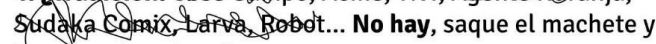
haga camino al andar.

5. Viñeta con viñeta vas a contar una historia. Cada viñeta es un mundo, el conjunto de viñetas contará una historia que aquí no interesa.

6. Trata de publicar tus cómics sin gastar un solo peso. Nadie te va a editar, si te editan te roban... Igual, nadie compra lo que hacés.

7. Un pacto con vos mismo. Vos sabés que dibujar ya es un oficio, no una cosa pasar "el rato".

8. Evita el "show", el "perfomance". Dibujar es serio.

Acepta invitaciones a dibujar entre colegas, pero

la verdadera obra se hace solo.

9. No existe una técnica, no hay una sola forma de dibujar y de contar buenas historias. Pero, cada vez, trata de dibujar y contar mejor.

10. Aquí, en Colombia, NADIE tiene autoridad para hablar de historietas, Podés romper todo, sienta el culo a dibujar. La obra habla por vos.

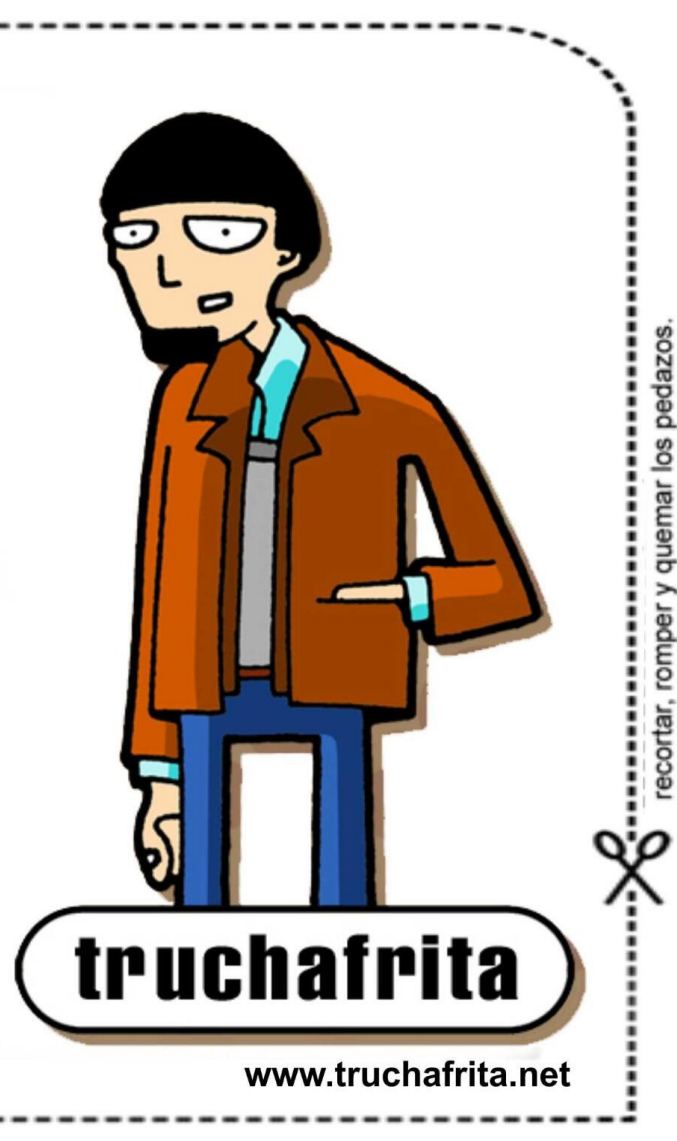

28. Decálogo del dibujante de historietas en Colombia. Compilado realizado por la Revista Larva. Imagen tomada de: https://twitter.com/revistalarva/status/455445579007406080

Y así profundizando en el zigzagueante y aún naciente mundo del cómic en Colombia encontramos algunos trabajos interesantes como la novela gráfica Caminos condenados de Cohete Cómics, la cual se basa en la investigación realizada por Diana Ojeda, sobre una región de los Montes de María que se vio afectada por el conflicto armado y su posterior posconflicto donde se estimuló el monocultivo de la palma de aceite, por este motivo, los pobladores sufrieron cambios drásticos en su rutina e incluso pasaron a tener escases de agua y alimentos en la zona, así como la implementación de territorios delimitados por los que antes transitaban libremente. 
Para los habitantes de esta región, los caminos condenados son aquellos que los nuevos dueños de terrenos cerraron, es decir, fueron "condenados" tal vez porque desaparecieron o porque los condenaron a ellos al hambre o a migrar a otras poblaciones. Los resultados de la visita de campo y del trabajo de investigación adelantado por Ojeda y su equipo sirvieron de base para la creación del guion y posteriormente del cómic, que cuenta con mucho detalle en los dibujos, un manejo de línea libre y una paleta de color basada en el blanco y negro, asemejándose al estilo de Sacco.

El conocimiento de este panorama permito discernir el mejor procedimiento posible para buscar una reconsideración y apropiación de temas ambientales entre el público objetivo, así, se plantea el desarrollo de La mano del oso como una novela gráfica donde un oso andino -como en una fábula- toma características antropomórficas para mostrar situaciones reales del oso.

Se busca también exponer desde la ficción y el humor, situaciones o momentos donde la gobernanza del medioambiente e incluso la gestión social colombiana, ha resultado insuficiente, de ahí que los referentes que se establecen sean cómics "documentales" y no piezas de sensibilización o de ficción.

El fomento a la lectura y el desarrollo de un universo gráfico se convierten en herramientas para atraer al público, para proponer un juego, donde ellos como receptores dialoguen alrededor de temas complejos entre ellos, o con las entidades que apoyan al proyecto o incluso mediante las redes sociales con el protagonista de la novela gráfica.

\subsection{Justificación}

El inventario de piezas destinadas al conocimiento medioambiental para adultos, no especialistas en estos temas redunda en informes, materiales periodísticos o didácticos que no aportan al día, día de los lectores y que pocas veces son consultados debido a su especificidad.

Así mismo, como se evidencia con el estudio de referentes, el cómic como recurso gráfico y narrativo genera gran impacto y sensibilidad en los lectores, quienes comprenden las metáforas de la ilustración de una manera más libre suscitando reflexiones propias. El cómic también permite que el lector se sienta disfrutando, cuando en realidad se está acercando a temas que pueden ser complejos. Este tipo de ludificación, como se comentó anteriormente hace parte de las tendencias actuales en educación y se han mostrado como parte de una metodología, que enriquece el aprendizaje autónomo. 
Debido a la escasa producción de piezas de contenido artístico y de entretenimiento, destinadas a público joven y adulto joven, que aborden desde la hibridación narrativa y gráfica la realidad e inviten a la reflexión y profundización sobre temas relacionados con el medioambiente, surge la idea de crear una novela gráfica que cuente una situación dolorosamente colombiana: la vulnerabilidad del oso andino.

Para hacer realidad este proyecto, se considera el desarrollo de una estrategia que involucra la realización de los siguientes pasos:

1. Para la edición impresa:

- Consolidar la impresión, distribución y venta mediante financiación obtenida por un convenio, contrato o por compra anticipada de ejemplares con ONG o fundaciones que lo quieran distribuir entre su público objetivo, existen gestiones adelantadas.

- Vender ejemplares de manera anticipada al público interesado.

- Gestionar y firmar un contrato con una editorial para así tener la línea de distribución tradicional de libros. O convertir a Casa Reflector en una editorial.

2. Ampliación universo online:

Llevar a cabo la gestión de una alianza o contrato con un medio masivo de comunican para generar una publicación con temática medioambiental desarrollada en paralelo a la novela gráfica. Dicha publicación será a manera de columna de opinión gráfica y profundizará temas de medioambiente, se busca posesionar a Elmo Sánchez en el imaginario del público objetivo.

\section{Merchandising:}

Si el personaje logra tener un impacto considerable (lo sabremos revisando las métricas de las redes sociales, así como los resultados de la distribución realizada por las ONG), se proyecta la creación y venta de material promocional derivado de los diseños de la novela gráfica en piezas como ropa, juguetes, elementos de papelería, entre otros, que permitan tener un portafolio más amplio e ingresos superiores.

\section{Replica con nuevos personajes:}

Siendo muy optimistas y teniendo resultados arrolladores se podría pensar en replicar la experiencia con nuevos personajes y/o universos. 
Estos pasos, además de plantear caminos de financiación diversos a los habituales para un libro, pueden entenderse como fases que se van evaluando, y de acuerdo, a los resultados, se da un paso adelante para recaudar dinero de otras fuentes.

\subsection{Objetivo general}

Crear una novela gráfica que muestre la condición del oso andino y su hábitat, teniendo como interés particular la consolidación de una experiencia de humor y sensibilización dirigida a jóvenes y adultos.

\subsection{Objetivo específicos}

- Crear los contenidos conceptuales, narrativos, artísticos, necesarios para la elaboración de la novela gráfica.

- Tener presencia de Elmo Sánchez en redes sociales.

- Desarrollar un modelo de negocio que garantice la distribución y venta del libro.

- Consolidar alianzas estratégicas con entidades medioambientales y medios de comunicación para aumentar los espacios de divulgación del personaje y el proyecto.

\subsection{Metas}

- Crear la novela gráfica La mano del oso.

- Generar estrategias y contenidos para las redes sociales de Elmo Sánchez.

- Concretar la impresión, distribución y venta de la novela gráfica La mano del oso.

- Consolidar mínimo tres alianzas con entidades de diversas índoles para asegurar la creación y distribución de la novela gráfica. 


\subsection{Presupuesto del proyecto}

\begin{tabular}{l|r|}
\hline \multicolumn{2}{|c|}{ Resumen presupuesto La Mano del Oso } \\
\hline Costos operativos & 200.000 \\
\hline Corrección de estilo & 700.000 \\
\hline Diagramación textos + ilustración (asesoría) & 500.000 \\
\hline Dirección o coordinación editorial & 500.000 \\
\hline Ilustración & 2.000 .000 \\
\hline ISBN & 75.000 \\
\hline Publicidad & 500.000 \\
\hline Total & 4.475 .000 \\
\hline & \\
\hline Impresión, encuadernación, empaque 500 unidades & 3.147 .550 \\
\hline Publicidad online & 500.000 \\
\hline Total & 3.647 .550 \\
\hline & \\
\hline Total costo mínimo & 8.122 .550 \\
\hline Total costo mínimo unitario & 16.245 \\
\hline \multicolumn{2}{|c|}{} \\
\hline Autor 1 10\% & 1.625 \\
\hline Autor 2 10\% & 1.625 \\
\hline Editorial 30\% & 4.874 \\
\hline Librería 35\% & 5.686 \\
\hline Distribución 30\% & 4.874 \\
\hline Total PVP & 34.927 \\
\hline
\end{tabular}




\subsection{Cronograma del proyecto}

Cronograma La mano del oso

\begin{tabular}{|l|l|l|l|l|l|l|l|l|l|l|}
\hline \multicolumn{1}{|c|}{ ACTIVIDAD } & MES 1 & MES 2 & MES 3 & MES 4 & MES 5 & MES 6 & MES 7 & MES 8 & MES 9 & MES 10 \\
\hline $\begin{array}{l}\text { Conceptualización del } \\
\text { proyecto }\end{array}$ & & & & & & & & & & \\
\hline Investigación & & & & & & & & & & \\
\hline Escritura & & & & & & & & & & \\
\hline Edición & & & & & & & & & & \\
\hline Dirección o coordinación & & & & & & & & & & \\
\hline Ilustración y diseño & & & & & & & & & & \\
\hline Color & & & & & & & & & & \\
\hline Corrección de estilo & & & & & & & & & \\
\hline Producción & & & & & & & & & \\
\hline Impresión Libro 500 unidades & & & & & & & & & & \\
\hline Promoción y distribución & & & & & & & & & \\
\hline Distribución - transporte & & & & & & & & & & \\
\hline Publicidad & & & & & & & & & & \\
\hline Redes sociales & & & & & & & & & & \\
\hline Lanzamiento & & & & & & & & & \\
\hline
\end{tabular}




\section{Conclusiones}

- El inventario de piezas que hibridan narración, gráficos y sensibilización medioambiental, a pesar de estar en crecimiento y de presentar -como se vio en otro apartado de este documento- una cantidad de piezas considerable no tiene en cuenta el público joven, es decir, son muy pocas las obras que van dirigidas a este segmento del público, dejándolo desatendido.

- A pesar de la información que el DANE y la Cuenta Satélite de Cultura brindan sobre consumos culturales, sería ideal profundizar la investigación acerca del público joven y adulto joven conocer sus gustos, acercamientos a redes sociales, hábitos de lectura, relacionamiento con el arte y los gráficos, para determinar con mayor seguridad el plan de comunicaciones, canal de distribución y demás acciones del proyecto que van dirigidas a ellos(as).

- El desarrollo y proceso de creación de obras que mixturan procesos artísticos además de requerir de tiempo, son un cúmulo de velocidades, intenciones e intereses, que sumadas a labores de gestión representan un gran reto, como el proyecto inicial abarcó la realización de dos pilotos, el de la novela gráfica La mano del oso y el del recorrido turístico Directo Memoria, los tiempos de realización han sido más largos de lo inicialmente planteado.

- Las situaciones sociales, políticas y en este caso salubres, también afectan el desarrollo de proyectos, la cancelación de eventos y tener que desarrollar labores desde casa ha impactado no solo los procesos de creación sino también las labores de gestión, aumentando tiempos de respuesta e incluso ocasionando cancelaciones. En situaciones como ésta, la adaptabilidad se vuelve indispensable, ajustar nuevos planes y trazar la ruta siempre con el derrotero de llegar a buen puerto.

- El desarrollo del cómic en Colombia es de suma importancia, sin embargo, para el fortalecimiento de esta industria es necesario contar con lectores, enseñar y crear público, como lo señala la editora de novela gráfica de Salamandra Editores, Catalina Mejía: "Pero, sobre todo, una campaña de fomento a la lectura de cómic. Sin lectores no hay industria, a pesar de que cada vez se publique más y mejor. Necesitamos crear lectores. Ese es el lema y el objetivo principal". 


\section{Listado de referencias consultadas}

- $\quad$ Aguirre, C., Díaz, H., Guerra, P., y Ojeda, D. (2016). Caminos condenados. Bogotá: Cohete Cómics.

- Casas, R., Saravia, E. y Suarez, M. (2015) El sector editorial en Colombia: una breve aproximación a sus dinámicas. Ministerio de Cultura. Recuperado a partir de: https://oibc.oei.es/uploads/attachments/43/El sector editorial en Colombia.pdf

- Castellanos, J., Cifuentes, D., Saravia, E., Silva, P., (2016) La red editorial en Colombia: Compilación de investigaciones sobre el sector. Lado B. Recuperado a partir de: https://culturayeconomia.org/wp-content/uploads/Estudio-sectorEditorial-Lado-B.pdf

- Cardenas, M. y Mejía, C. (25 de julio de 2019) Necesitamos crear más lectores de cómic. Revista Blast. Recuperado a partir de https://revistablast.com/entrevistas/necesitamos-crear-mas-lectores-de-comic/

- CERLALC (2017) El libro en cifras. Boletín estadístico del libro en Iberoamérica. Recuperado a partir de: http://www.cerlalc.org/wpcontent/uploads/publicaciones/olb/PUBLICACIONES_OLB_El libro_en_cifras_11 3 10817.pdf

- Conde, J. (2019). Del Cómic a la novela gráfica: mutaciones editoriales de la historieta colombiana en el siglo XXI. Artículo en la Revista de pensamiento, crítica $y$ estudios literarios latinoamericanos. P. 61-77

- Congreso de Colombia (22 de diciembre de 1993) Artículo 2. Ley sobre democratización y fomento del libro colombiano. (Ley 98 de 1993). Recuperado a través de: https://www.funcionpublica.gov.co/eva/gestornormativo/norma.php? $\underline{\mathrm{i}=27901}$

- Correa, J. (2010). El Cómic, invitado a la biblioteca pública. Bogotá. Centro Regional para el Fomento del Libro en América Latina y el Caribe - CERLALC. Recuperado a partir de: https://cerlalc.org/wp content/uploads/publicaciones/olb/PUBLICACIONES OLB El-comic-invitado-a-labiblioteca-publica v1 01012010.pdf 
- Dahlman, C. Holland, E. \& Sacco, J. (22 de noviembre de 2016) Graphic Geopolitics: An Interview with Comics Artist Joe Sacco. VOL. 22, NO. 1, 209-210 Recuperado a partir de http://dx.doi.org/10.1080/14650045.2016.1254622 Traducción de Valentina del Pino.

- DANE. (2018). Boletín Técnico Encuesta de consumo cultural (ECC) 2017. Recuperado a partir de https://www.dane.gov.co/index.php/estadisticas-portema/cultura/consumo-cultural

- DANE. (2018). Infografía Censo 2018 Total Nacional Colombia. Recuperado a partir de https://www.dane.gov.co/index.php/estadisticas-portema/demografia-y-poblacion/censo-nacional-de-poblacion-y-vivenda-2018.

- Deleuxe, G. y Guattari, F. (1980). Mil mesetas, Capitalismo y Esquizofrenia. España: Pre-Textos.

- González, F. (2020). Principales aspectos que deben considerarse al momento de negociar un contrato de edición. Texto. Recuperado a partir de https://cerlalc.org/principales-aspectos-que-deben-considerarse-al-momento-denegociar-un-contrato-de-edicion/.

- González, J. y Wischenbart, R. (2019). El espacio iberoamericano del libro 2018 CERLALC. Recuperado a partir de: https://cerlalc.org/wpcontent/uploads/2019/04/EIL2018 2.pdf

- Jiménez Quiroz, D. (2014). Páginas en emergencia: un itinerario de la novela gráfica en Colombia. Boletín Cultural y Bibliográfico, 48 (86). Recuperado a partir de https://publicaciones.banrepcultural.org/index.php/boletin cultural/article/view/7 $\underline{524}$

- Kirtley, S., Garcia, A. \& Carlson, E. (2020). With Great Power Comes Great Pedagogy: Teaching, Learning, and Comic Books. United States of America. University Press of Mississippi.

- Malagón, S. y Mejía, C. (12 de septiembre de 2015) Cómo editar novela gráfica. El Espectador. Recuperado a partir de https://www.elespectador.com/noticias/cultura/como-editar-novela-grafica/ 
- Manguel, A. (2015). El viajero, la torre y la larva: el lector como metáfora. Ciudad Autónoma de Buenos Aires: Fondo de Cultura Económica.

- Observatorio de la región Bogotá, Cundinamarca. Recuperado a partir de https://www.ccb.org.co/observatorio/Economia/Economia-dinamica-incluyente-einnovadora/Poblacion-pobreza-y-desigualdad/En-los-rangos-de-edad-mas-joveneshay-mayor-numero-de-poblacion-masculina

- Quintero J. y Sacco, J. (2 de octubre de 2017) El cómic como arte total: entrevista a Joe Sacco. Revista Dinners. Recuperado a partir de https://revistadiners.com.co/cultura/50175 comic-arte-total-entrevista-joe-sacco/

- Rey, G. (23 de enero de 2019) Más allá de la frivolidad: el consumo cultural de los colombianos. El Tiempo. Recuperado a partir de https://www.eltiempo.com/cultura/musica-y-libros/estadisticas-sobre-el-consumocultural-de-los-colombianos-en-el-2017-318372

- Sacco, Joe. (2015) Palestina. España: Planeta Cómic. 


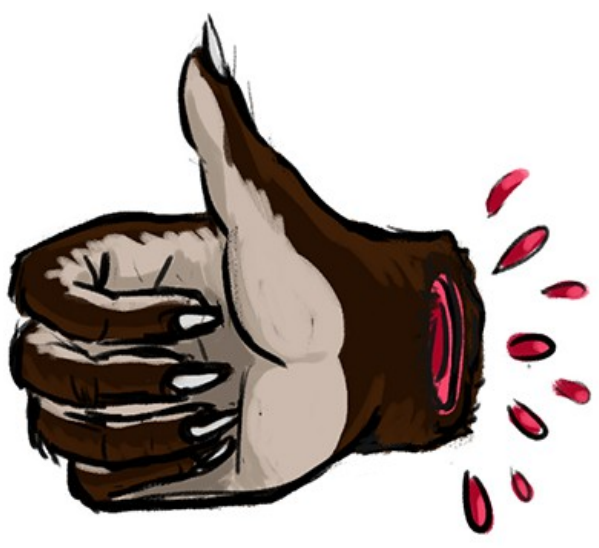

